\title{
Inorganic anion removal using micellar enhanced ultrafiltration (MEUF), modeling anion distribution and suggested improvements of MEUF: A review
}

\author{
Ming Chen ${ }^{1,2^{*}}$, Chad T. Jafvert ${ }^{3,4}$, Yichen $W^{5}$, Xiaoqiang $\mathrm{Cao}^{6}$, Nicholas P. Hankins ${ }^{2}$ \\ ${ }^{1}$ School of Civil Engineering, Southeast University, Nanjing, 210096, China \\ ${ }^{2}$ Department of Engineering Science, University of Oxford, Oxford, OX1 3PJ, UK \\ ${ }^{3}$ Lyles School of Civil Engineering, Purdue University, West Lafayette, IN 47907, US \\ ${ }^{4}$ Division of Environmental \& Ecological Engineering, Purdue University, West Lafayette, IN 47907, US \\ ${ }^{5}$ Department of Chemical Engineering, McMaster University, Hamilton, ON L8S 4L8, Canada \\ ${ }^{6}$ College of Safety and Environmental Engineering, Shandong University of Science and Technology, Qingdao \\ 266590, China
}

*Corresponding author: Ming Chen, ming.chen@eng.ox.ac.uk

\begin{abstract}
Surfactants have been used often in environmental remediation strategies due to their special amphiphilic nature which alters surface and water interfacial properties. When the aqueous concentration of a cationic surfactant far exceeds the critical micelle concentration (CMC), a large concentration of cationic micelles will form in water. These micelles each consist of tens to hundreds of surfactant monomers, and collectively can be utilized as nano-sized ion exchangers to assist with ultrafiltration separation (i.e., removal) of anionic pollutants from natural waters or wastewaters. Target anionic pollutants include nitrate, phosphate, arsenate and chromate. However, most polluted waters contain a complex mixture of anions, with these different anions competing for the micellar pseudo-phase, thus potentially reducing the overall removal efficiency of the target anions. Further, loss of surfactant monomers through the membrane also reduces process efficiency as replenishment of surfactant over time is required. In this review, the existing research on inorganic anion removal by micellar enhanced ultrafiltration (MEUF) and similar processes
\end{abstract}


are summarized. Operating condition factors are discussed, including pressure, membrane pore size, surfactant-contaminant concentration ratios, and water chemistry conditions (i.e., $\mathrm{pH}$, salinity). Because most micellar surfactant - anion interactions are through outer-sphere electrostatic association, emphases in this review are given to the measurement of selectivity coefficients used for identifying the affinity of anions to the micelles, which generally decreases in the order of: $\mathrm{Fe}(\mathrm{CN})_{6}{ }^{3-}>\mathrm{CrO}_{4}{ }^{2-}>\mathrm{SO}_{4}{ }^{2-}>\mathrm{HAsO}_{4}{ }^{2-}>\mathrm{HPO}_{4}{ }^{2-}>\mathrm{NO}_{3}{ }^{-}>\mathrm{Cl}^{-}>$ $\mathrm{HCO}_{3}^{-}>\mathrm{H}_{2} \mathrm{AsO}_{4}^{-}>\mathrm{H}_{2} \mathrm{PO}_{4}^{-}>\mathrm{F}^{-}>\mathrm{IO}_{3}^{-}$; and to the development of a speciation model, based on these selectivity coefficients, for predicting anion distribution in micellar solutions. Ways to address improved process efficiency, as well as future challenges and opportunities, are also discussed.

Keywords: Micellar enhanced ultrafiltration (MEUF); Anions removal; Cationic surfactant; Ion exchange; Selectivity; Modeling 
Contents

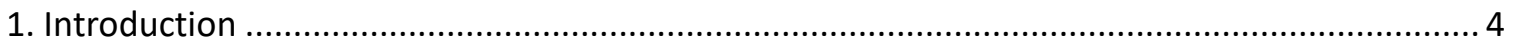

2. Surfactant and micelle ............................................................................................... 5

3. Micellar enhanced ultrafiltration (MEUF) ..................................................................... 8

4. Anionic contaminant removal using cationic surfactant micelles....................................... 13

4.1 Cationic surfactants used in MEUF............................................................................ 13

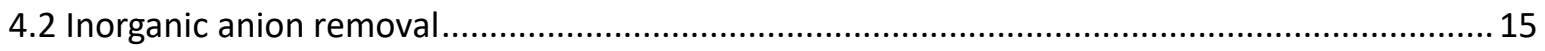

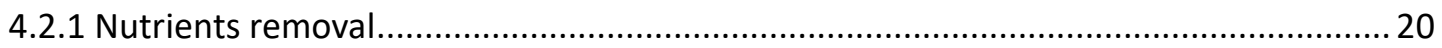

4.2.2 Arsenic (V) removal ............................................................................... 21

4.2.3 Chromium (VI) removal .............................................................................. 23

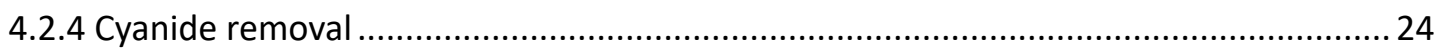

4.2.5 Other anion removal .................................................................................... 25

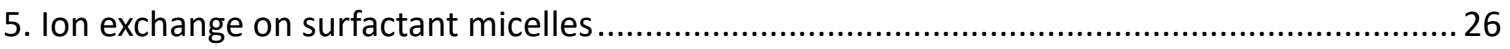

5.1 Selectivity coefficients of anions for cationic surfactant micelles.......................................27

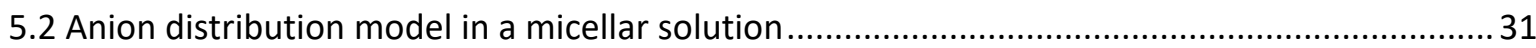

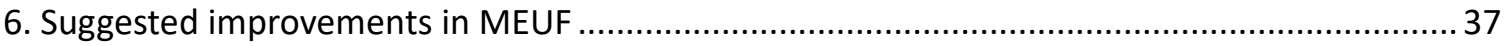

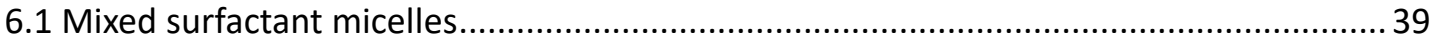

6.2 Activated carbon adsorption combined with MEUF ...............................................40

6.3 Cross-linking of surfactant micelles ................................................................... 41

6.4 Surfactant-polymer aggregate enhanced membrane separation ................................. 42

7. Challenges and future opportunities of MEUF ............................................................. 44

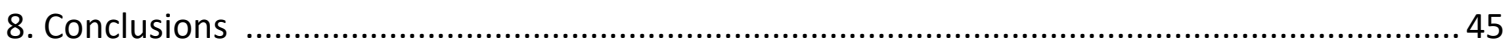




\section{Introduction}

As a type of molecular structure with special amphiphilic properties, surfactants have been used to enhance environmental remediation processes [1-3], to improve oil production [4-6], to modify the surface of functional materials [7-10], to improve performance of membrane separation processes $[11,12]$, to assist with catalysis $[13,14]$, to solubilize non-polar compounds [15], and to assist with drug delivery [16, 17] for decades. Among these applications, surfactant micelle-assisted ultrafiltration separation processes (known as micellar enhanced ultrafiltration, MEUF) for contaminants removal from water has been studied for more than 30 years, ever since the 1980s when Scamehorn first introduced the use of micelles as vesicles to effectively remove organic molecules from aqueous streams during ultrafiltration [18]. Since that time, the removal of cationic metals and removal of toxic organic pollutants by surfactant micelles across ultrafiltration membranes has been widely researched and reviewed [19-23]. As a result of the human activities, including industrial development, the discharge of many types of anionic contaminants into the environment has occurred, often causing severe water pollution issues. Commonly occurred inorganic anionic pollutants in the water environment include nutrients (e.g., nitrate and phosphate), metallic anions such as metal oxyanions (e.g., chromate and arsenate) and metal-anion complex (e.g. ferricyanide), and some other anions of concern (e.g. fluoride). Most of these anions pose a threat to human health due to their high toxicity or other health effects. High costs associated with their recovery from water, or simply difficulty in recovery from water often makes them problematic as pollutants. As a water treatment strategy to remove inorganic anions, MEUF has been studied; however, these studies collectively have not been critically reviewed. Many studies have been conducted to investigate the performance of MEUF for removal of various ions and how removal is 
influenced by different operating and water quality parameters. However, of special concern are: (1) Competition from other anions in the water during MEUF, as naturally occurring bicarbonate $\left(\mathrm{HCO}_{3}{ }^{-}\right)$and sulfate $\left(\mathrm{SO}_{4}{ }^{2-}\right)$ may greatly influence removal efficiency of target anions; and (2) loss of surfactant monomers across the membrane, as micelle self-assembly is a dynamic process with monomers always present in solution, basically at a concentration equal to the critical micelle concentration (CMC). Hence, in this review, the basic principle of MEUF are first summarized through an introduction to surfactants, micelles, and ultrafiltration separation assisted by micelles; then, literature that specifically focuses on inorganic anion removal using MEUF is summarized with respect to parameters that influence MEUF performance, including the relative affinities of common anions to cationic surfactant micelles, modeling anions distribution in a micellar solution, and improvement methods of solving the issue of the loss of surfactant monomers during MEUF.

\section{Surfactant and micelle}

Surfactants are a class of chemicals possessing both polar and nonpolar functional groups. The polar (i.e., hydrophilic) head group is typically either an ionic moiety (e.g., sulfate, benzenesulfonate, carboxylate, or quaternary ammonium salt), or a non-ionic moiety, such as a polyethoxylate group. The nonpolar (i.e., hydrophobic) "tail" group is typically a long chain (i.e., 10 to 20 carbon atoms) hydrocarbon, and may include two such tail groups, known as a Gemini-surfactant [24]. The amphiphilic nature makes surfactant molecules soluble to some degree in both aqueous and non-aqueous liquids. Surfactant molecules in the aqueous phase may diffuse and adsorb at the interface between two phases (water/air or water/oil), increasing the interfacial area and reducing the interfacial tension as shown in Figure 1, where cetyltrimethylammonium bromide (CTAB) and cetylpyridinium chloride (CPC) are representative surfactant examples (at $20^{\circ} \mathrm{C}$ ). From the 
figure, it is clear that both CTAB and CPC decrease the water surface tension and increase solution conductivity as the concentration increases. Beyond a certain surfactant concentration, the decrease in surface tension (and increase in conductivity) attenuates significantly. This concentration value, referred to as the critical micelle concentration (CMC), is equal to the concentration of surfactant molecules in solution above which nano-sized aggregates (i.e., micelles) start to form spontaneously, and as the figure indicates, can be determined by measuring the surface tension or conductivity of aqueous surfactant solutions as a function of surfactant concentration (e.g., around $0.9 \mathrm{mM}$ for both CTAB and $\mathrm{CPC}$, as shown in Figure 1). From Figure 1a, at the monomer concentration at which micelles begin to form, addition of more surfactant results in negligible change in the surface tension; and from Figure 1b, once surfactant molecules form micelles, the counter-ions (i.e., ions of opposite charge from the surfactant) associate with the micellar pseudo-phase such that addition of more surfactant leads to an attenuated increase in conductivity. From a thermodynamic standpoint, micelle formation can be thought of similarly as a precipitation reaction. Both occur when the aqueous phase concentration reaches a specific value, and this value is affected by any factor that alters the aqueous phase activity of the surfactant, including temperature, pressure, and ionic strength. Variation of the $\mathrm{CMC}$ with temperature has been studied for different surfactants [25-27]. Generally, the CMC of ionic surfactants decreases to a minimum value with the increase of temperature and then increases, following a 'U-shaped' CMC versus temperature plot. The minimum CMC usually occurs between $0-40^{\circ} \mathrm{C}$ (typically at room temperature) [28]. The formation of surfactant micelles is guided by thermodynamic rules, and the standard enthalpy can be derived by the van't Hoff equation [29, 30]. For example, Zieliński et al. [25] reported that the standard enthalpy of micelle formation of alkyltrimethylammonium bromides is zero at the minimum CMC, with a 
positive or endothermic value on the lower temperature side and a negative or exothermic value on the higher temperature side. The entropy change of micelle formation is generally positive, due to the hydrophobic effect, and it is this which allows the free energy of micelle formation to be negative (i.e. a spontaneous process). Among surfactant species, the value of the $\mathrm{CMC}$ is a function of the head group size, the hydrophilicity of the head, the tail group length and branching, and the type and concentration of counter-ions present $[24,27]$.
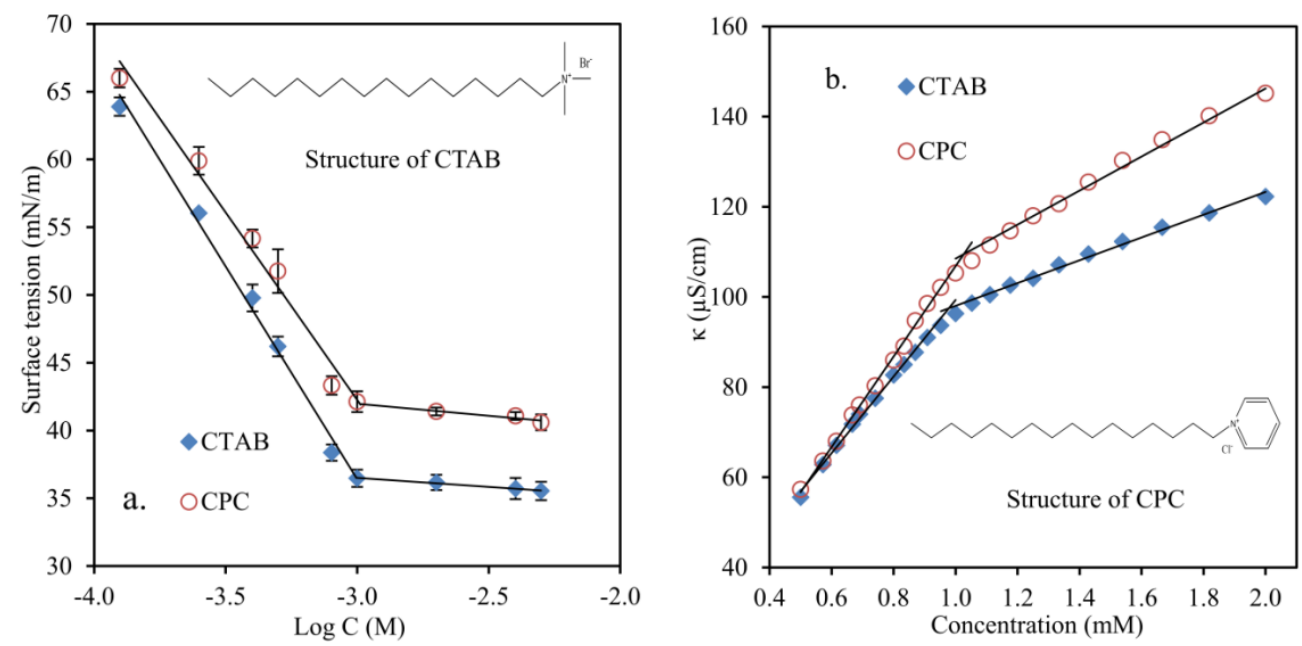

Figure 1. Surfactant solution properties as a function of surfactant concentration at $20^{\circ} \mathrm{C}$ :

(a) Solution surface tension; (b) Solution conductivity. [27]

The surfactant molecules in the micelles are in equilibrium with free surfactant molecules or ions in solution (monomers), with this concentration of water dissolved surfactant monomers in the solution equal to the CMC. At concentrations above the surfactant's CMC, colloidal-sized micelles will be present in the aqueous solution, and as the total concentration is increased, these added surfactant molecules all form micelles. In an aqueous solution, the hydrophobic tails form the organic core of the micelles, and the hydrophilic head groups are at the outer interface or surface in contact with the aqueous phase. In contrast, reversed micelles form in organic solvents. The shape of the micelles depends on the structure of the surfactant molecules, their concentration, and the 
temperature and ionic strength of the solution, and even the flow conditions [31]. Micelles are commonly approximately spherical in shape, with other shapes, including elliptical, cylindrical, worm-shaped, and bilayer also possible [32,33]. Typical spherical micelles are composed of 10 to 100 surfactant monomers, and the typical size is several nanometers in diameter, depending on the length of the surfactant molecules. As shown in Figure 2, most CTAB and CPC micelles range in size from 1 to $5 \mathrm{~nm}$ (hydrodynamic diameter) without other electrolytes present, as determined by dynamic light scattering (DLS), which emphasizes the particles with the highest number. If micelles are composed of ionic surfactants, the micelle aggregates can consist of tens to hundreds of monomers, and basically are nano-sized ion exchangers with hydrophilic ionic head groups on the surface of the micelles and hydrophobic central cores. Counter-ions in the aqueous solution ion-pair with the ionic surface of the surfactant micelles via electrostatic interaction, in most cases, such that this association can be treated as an aqueous phase ion exchange process.

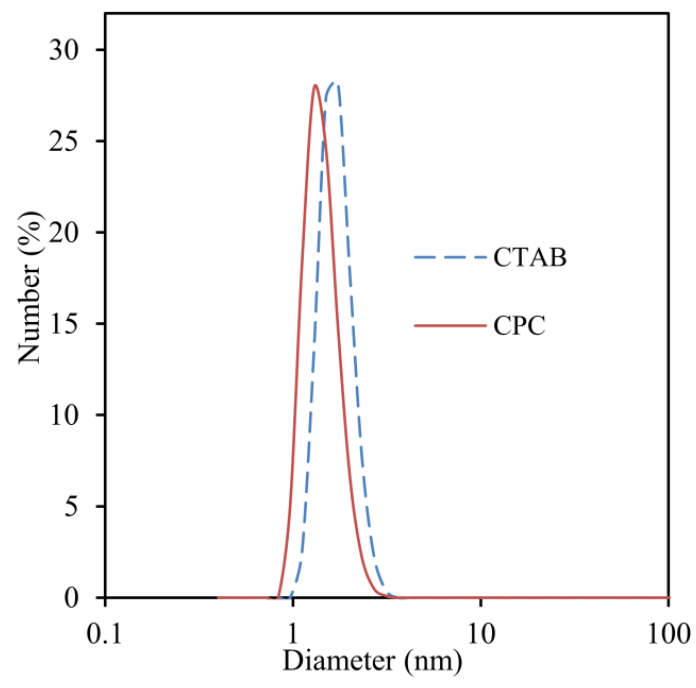

Figure 2. Micelle size distribution at surfactant concentrations of $5 \mathrm{mM}$ [27].

\section{Micellar enhanced ultrafiltration (MEUF)}


As a semipermeable membrane, ultrafiltration (UF) membranes can be used to separate solutes and colloidal particles with high molecular weight (e.g., proteins, viruses) from those with low molecular weight (including the water molecules) by applying a pressure or concentration gradient. Ultrafiltration has been utilized widely in wastewater treatment and water reclamation due to the advantages of low energy consumption and high separation efficiency. The combination of surfactant micelles and UF is known as micellar enhanced ultrafiltration (MEUF), which has been considered as a promising water and wastewater treatment and resources recovery strategy [22]. The application of MEUF was first introduced in the 1980 s $[18,34,35]$, based on previous fundamental studies [36, 37]. This technology has been researched for decades and shown to be a viable separation process for removing various contaminants from water, including heavy metal species [38-42], dyes [43-45], and toxic organic compounds [18, 46, 47]. A schematic of the MEUF process (e.g., with a cationic surfactant) is shown in Figure 3. The basic principle of this strategy is that ionic pollutants with smaller sizes than the membrane pores are rejected by the UF membrane due to association with the larger surfactant micelles. Traditional ultrafiltration is ineffective at removing molecular and elemental ions and other low-molecular weight organic compounds (e.g., <1000 Da) since they can pass through the ultrafiltration membrane with the permeate. However, a UF membrane with an appropriate molecular weight cut-off (MWCO) can retain these species if they associate with the micelles, as the size of the micelles is larger than the pore diameter of the membrane. Therefore, the rejection of the nano-scale micelles by the membrane results in the removal of any ions associated with the surface of the micelles and also removal of any neutral organic molecules that are solubilized within the organic core of the micelles during the ultrafiltration process. The permeate that passes through the membrane can have greatly 
reduced concentrations of these ions or molecules compared to the bulk solution retained by the membrane. A typical scheme of the experimental system for the MEUF process is shown in Figure 4 [48]. The bulk solution is mixed with surfactant in the tank, followed by separation through the UF membrane under air pressure. The permeate with greatly reduced contaminants can be discharged, while the retentate is returned to the mixing tank. The back-flush device is used for membrane cleaning [49]. This process requires much lower pressures (i.e., energy input) compared to reverse osmosis (RO), yet can have relatively high performance in both the removal of contaminants and in the flow rate. Furthermore, because the surfactant micelles are present in the bulk aqueous phase, MEUF is a rapid process compared to heterogeneous treatment processes, such as ion exchange on a resin. However, continuous loss of surfactant monomers through UF membrane is an issue for this technology, since self-assembled surfactant micelles are in rapid equilibrium with monomers in the aqueous phase, the concentration of which is maintained at the $\mathrm{CMC}$. These surfactant monomers pass through the UF membrane due to their smaller size compared to that of membrane pores, and may be considered as pollutants in the treated water. To minimize the effect of surfactant loss, a surfactant can be selected that minimizes loss and other negative effects, including those with low CMC values, large micelles, high solubilization, and those that are non-toxic or environmentally friendly. Selection of surfactant with low $\mathrm{CMC}$ values can reduce the free monomers in the permeate; larger micelles are beneficial for the application of UF membranes with larger pore sizes, thereby reducing energy input; a higher solubilization and lower Krafft temperature (the temperature at which the solubility equals the $\mathrm{CMC}$ at the same temperature, where the lower limit of micelle formation occurs) of the surfactant leads to more micelles being formed in the solution. 
Considering that the surfactant used in MEUF may account for a large portion of the cost, the recovery of the surfactant is essential from an economical perspective. The surfactant monomer which passes through the UF membrane can be recovered from the permeate using a chemical method $[50,51]$; while the recycle of the surfactant in the retentate can be achieved by changing temperature or $\mathrm{pH}$, or through an ion exchange method [52-55].

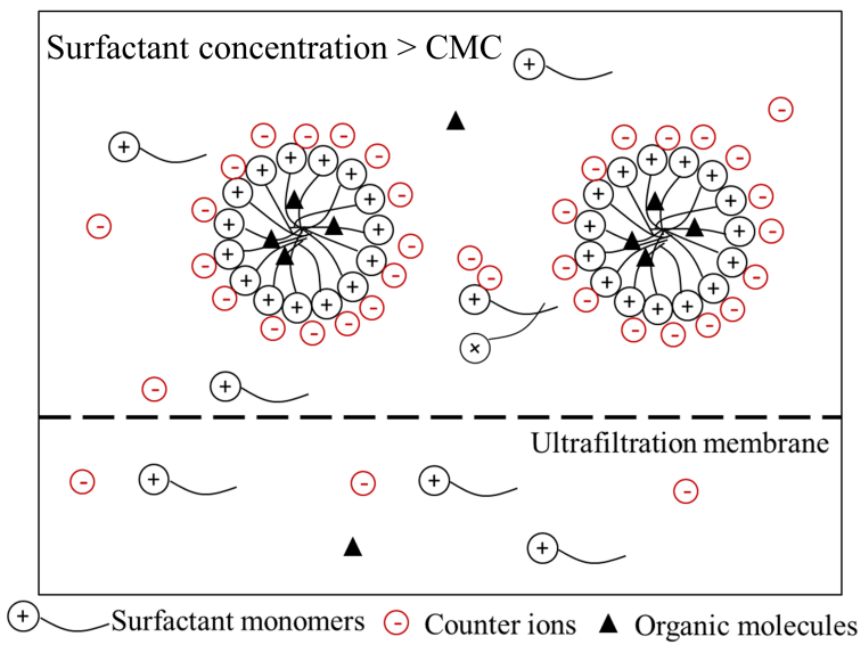

Figure 3. The basic principle of surfactant micellar enhanced ultrafiltration.

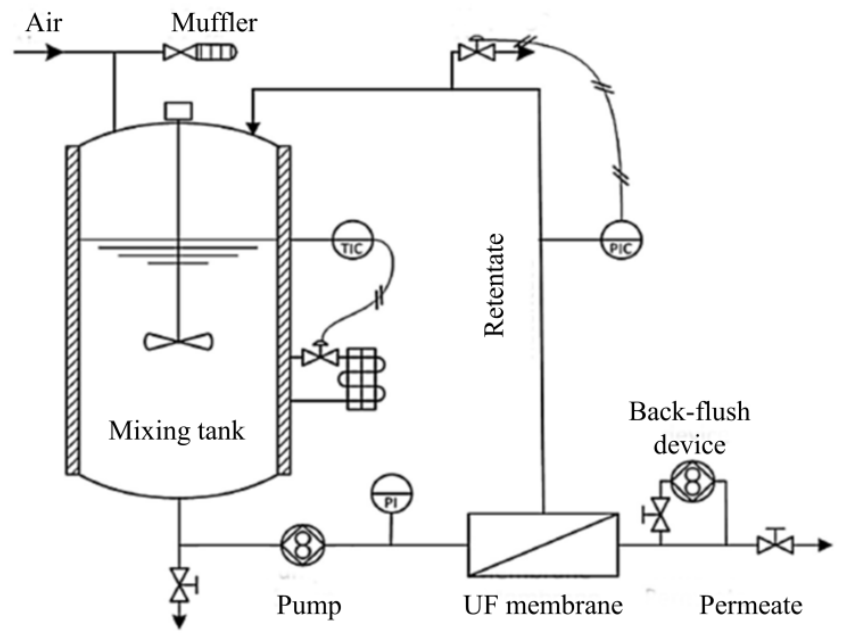

Figure 4. A typical sketch of the MEUF experimental apparatus [48].

A key point of MEUF is that an appropriate membrane must be chosen to separate efficiently the surfactant micelles and contaminants from the water. The necessary 
molecular weight cut-off (MWCO) or pore size of the membrane can be determined based on the surfactant micelle size. Using a membrane with a larger MWCO will cause loss of more surfactant, while using one with too low of a MWCO may require the input of more energy (i.e., higher operating pressure) or reduced flow. Because the typical size of surfactant micelles is several nanometers in diameter, UF membranes with MWCOs ranging from 3 to $10 \mathrm{kDa}$ typically are used. Some studies do report the effective use of higher MWCO membranes (up to $100 \mathrm{kDa}$ ), as the gel layer formed on the membrane surface, due to concentration polarization, increases the rejected micelles and associated ions [56]. However, the adsorption or deposit of surfactant on the membrane surface, blockage by surfactant aggregates in pores, concentration polarization, and the formation of a gel layer or cake formation are all causes of membrane fouling and may reduce the fluid flux and increase the operating pressure $[57,58]$. Indeed, fouling results in increased operational costs, due to increased energy demand, additional labor for maintenance, cleaning chemical costs, and shorter membrane life [59]. Commonly used UF membrane materials include cellulose, cellulose acetate, polyethersulfone (PES), polysulfone (PS), polyacrylonitrile (PAN), and ceramic materials. The MEUF process is usually performed under two configurations: dead-end filtration and cross-flow filtration (shown in Figure 5 [60]). The former is a conventional form of filtration, mostly using flat sheet membranes in which the contaminants in solution are rejected by the membrane, and the filtrate is released at the bottom of (below) the membrane. This process can easily be operated in batch mode. For the cross-flow type, the feed flows parallel to the membrane surface, and is generally operated with continuous input and filtrate flow. Dead-end MEUF systems usually have higher removal efficiencies than cross-flow systems, while cross-flow filtration has been preferred in field applications because of the higher flow rates achieved by the higher 
surface-area cross-flow filtration systems than by the flat-sheet dead-end filtration systems $[20,61]$
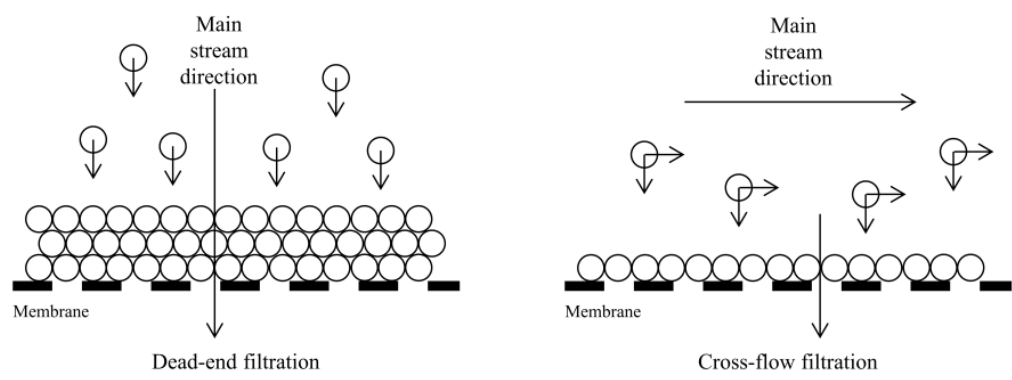

Figure 5. Two operating configurations of MEUF [60].

\section{Anionic contaminant removal using cationic surfactant micelles}

\subsection{Cationic surfactants used in MEUF}

The positive charge of cationic surfactant micelles attracts anionic pollutants, whereas the hydrophobic core attracts nonpolar organic molecules through hydrophobic force. Numerous cationic surfactants are available, however only a few have been used in MEUF for anions removal due to commercial availability, cost, and chemical properties, such as the CMC value. Table 1 provides a short list of some cationic surfactants that have been reported in the literature to be used for the removal/recovery of anions from water. The table indicates that an important class of cationic surfactants is the quaternary ammonium salts of different tail lengths, with the CMC value decreasing as the length of the hydrophobic tail group increases. For example, the CMC value of OTAB with an 18-carbon tail group is only $0.65 \mathrm{mM}$, much lower than that of DTAC $(10 \mathrm{mM})$ with only 12 carbons in its tail. In addition, counter-ions with higher affinities for the micelle result in lower CMC values, e.g., $\mathrm{Br}^{-}$displays a stronger electrostatic attraction than $\mathrm{Cl}^{-}$to $\mathrm{CTA}^{+}$micelles [62], resulting in a lower CMC value for CTAB $(0.92 \mathrm{mM})$ compared to that of CTAC $(1.58 \mathrm{mM})$. A previous 
study on n-alkylammonium salts indicates that $C M C$ values increase through the sequence of counter-ions: $\mathrm{NO}_{3}^{-}<\mathrm{Br}^{-}<\mathrm{Cl}^{-}$[63]. Considering the cost and commercial availability, CTAB is the most widely used quaternary ammonium salt surfactant in practice. Another widely used surfactant is CPC, with a pyridinium head group and the same tail group as CTAB (the CMC is also similar to $C T A B)$. Utilization of a surfactant with a low $C M C$ value is beneficial as less surfactant is lost in the permeate during ultrafiltration. In particular, CTAB and CPC possess longer tail groups and lower $\mathrm{CMC}$ values comparing to the surfactant extensively used for cationic metals removal in MEUF, sodium dodecyl sulfate (SDS, 12 carbons in the tail group, with a $\mathrm{CMC}$ of $8.2 \mathrm{mM}$ ). Hence, fewer monomers are lost during anion removal using CTAB or CPC than during cation removal using SDS.

Table 1. Common cationic surfactants employed for anion removal

\begin{tabular}{|c|c|c|c|c|c|}
\hline Surfactant name & Abbreviation & $\mathrm{CMC}(\mathrm{mM})$ & $\begin{array}{c}\text { Molecule } \\
\text { weight }(\mathrm{g} / \mathrm{mole})\end{array}$ & $\begin{array}{c}\text { Carbon } \\
\text { number in the } \\
\text { tail group }\end{array}$ & Chemical structure \\
\hline $\begin{array}{l}\text { Dodecyltrimethylammonium } \\
\text { chloride }\end{array}$ & DTAC & $10[64]$ & 263.89 & 12 & \\
\hline $\begin{array}{l}\text { Tetradecyltrimethylammonium } \\
\text { bromide }\end{array}$ & TTAB & $3.4[65]$ & 336.39 & 14 & \\
\hline $\begin{array}{l}\text { Cetyltrimethylammonium } \\
\text { bromide }\end{array}$ & CTAB & $0.92[66]$ & 364.45 & 16 & \\
\hline $\begin{array}{l}\text { Cetyltrimethylammonium } \\
\text { chloride }\end{array}$ & CTAC & $1.58[67]$ & 320.00 & 16 & \\
\hline $\begin{array}{l}\text { Octadecyldimethylammonium } \\
\text { bromide }\end{array}$ & OTAB & $0.65[68]$ & 392.5 & 18 & \\
\hline Cetylpyridinium chloride & CPC & $\begin{array}{l}0.90[66] \\
1.08[69]\end{array}$ & 358.00 & 16 & \\
\hline Octadecylamine acetate & ODA & $0.90[66]$ & 329.05 & 18 & \\
\hline
\end{tabular}




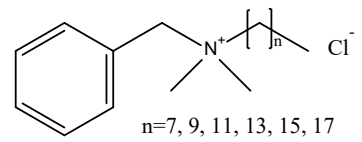

\subsection{Inorganic anion removal}

MEUF has been shown to remove various inorganic anions including nitrate, phosphate, arsenate, chromate, and ferricyanide. When the aqueous concentration of a cationic surfactant far exceeds the CMC value, there will be a large number of positively charged micelles in the water which behave as an anion exchange nanomaterial. Aqueous phase anions with greater affinity for the charged micelles will replace the original counter-ions associated with the surfactant salt. Once associated with the micelle surface, they will be rejected by UF membranes. Table 2 lists reported studies that have focused on anionic inorganic contaminant removal by cationic surfactant micelles across UF membranes. Often, removal efficiency for a specific anion has been examined as a function of surfactant type, water chemistry (e.g., $\mathrm{pH}$ and competing ions), and MEUF operating conditions including the concentration of the surfactant, membrane MWCO, and operating pressure. It can be seen from the table that CPC and CTAB have been used most widely in these studies. Overall, CPC has better removal efficiency for various anionic contaminants than $C T A B$, since the initial anion on $C T A B$ is $\mathrm{Br}^{-}$, which has a greater affinity for the micelles than $\mathrm{Cl}^{-}$(in $\mathrm{CPC}$ ). The MEUF removal performance usually depends on the concentration ratio of the surfactant to the contaminants, and not on the concentration of the contaminants themselves. Increasing surfactant concentration causes a higher removal of contaminants, since more exchange sites on the micelle surface are available for association of the target anions. On the other hand, increasing surfactant concentration also leads to a significant decrease in membrane flux because of the formation of a surfactant gel layer or cake on the 
membrane surface. The effect of solution $\mathrm{pH}$ varies, and depends on the nature of the solute. Because the speciation of some metal and metalloid species, e.g., arsenic and chromium, changes with the $\mathrm{pH}$ of the solution, so the adjustment of $\mathrm{pH}$ can also influence MEUF performance. Considering the size of surfactant micelles, the MWCO of the UF membranes mostly ranges from 1 to $20 \mathrm{kDa}$, with pressures across the membrane ranging from 1 to 4 bar (0.1 to $0.4 \mathrm{MPa}$ ). Basically, a higher pressure causes a higher membrane flux. A lower MWCO leads to a greater removal of the contaminants, but also a lower permeate flux at a given pressure. 
Table 2. Previous studies on anion removal by micelles with UF (MEUF)

\begin{tabular}{|c|c|c|c|c|c|c|c|c|c|}
\hline $\begin{array}{l}\text { Target } \\
\text { Anions }\end{array}$ & Surfactants & MWCO & UF type & $\begin{array}{l}\text { Membrane } \\
\text { material }\end{array}$ & Pressure & $\begin{array}{l}\text { Observed } \\
\text { rejection }\end{array}$ & Parameters studied & Time & Ref. \\
\hline $\mathrm{NO}_{3}{ }^{-}$ & TTAB & $1,20 \mathrm{kDa}$ & Dead-end & $\begin{array}{l}\text { cellulose } \\
\text { acetate }\end{array}$ & 2 bar & $64-96 \%$ & $\begin{array}{l}\text { The effects of TTAB concentration and membrane MWCO; Mechanism and } \\
\text { efficiency of the MEUF process. }\end{array}$ & 1991 & {$[65]$} \\
\hline $\begin{array}{l}\mathrm{NO}_{3}^{-} \text {and } \\
\text { phosphate }\end{array}$ & $\mathrm{CPC}$ & $3,10 \mathrm{kDa}$ & Dead-end & cellulose & 2 bar & $\begin{array}{l}77-92 \% \text { of } \\
\mathrm{NO}_{3}^{-} \\
83-95 \% \text { of } \\
\text { phosphate: }\end{array}$ & $\begin{array}{l}\text { Individual anion and mixed anions removal by MEUF; The effect of } \\
\text { membrane MWCO. }\end{array}$ & 2003 & [70] \\
\hline phosphate & $\mathrm{CPC}$ & 3, $10 \mathrm{kDa}$ & Dead-end & $\begin{array}{l}\text { cellulose } \\
\text { acetate }\end{array}$ & 2 bar & $97 \%$ & $\begin{array}{l}\text { The effects of } \mathrm{pH} \text {, membrane } \mathrm{MWCO} \text {, and concentration ratio of CPC to } \\
\mathrm{PO}_{4}{ }^{3-} \text {. }\end{array}$ & 2004 & [71] \\
\hline $\begin{array}{l}\mathrm{NO}_{3}^{-} \text {and } \\
\text { phosphate }\end{array}$ & $\mathrm{CPC}$ & $30,10 \mathrm{kDa}$ & Cross-flow & acrylonitrile & 2 bar & $\begin{array}{l}>86 \% \text { of } \\
\mathrm{NO}_{3}^{-} ;>91 \% \\
\text { of } \\
\text { phosphate }\end{array}$ & $\begin{array}{l}\text { Individual anion and mixed anions removal by MEUF; The effects of CPC } \\
\text { concentration and membrane MWCO on anions removal and flux change } \\
\text { during the MEUF process. }\end{array}$ & 2004 & {$[60]$} \\
\hline phosphate & $\begin{array}{l}\text { CPC, CTAB, } \\
\text { ODA, BC }\end{array}$ & $10 \mathrm{kDa}$ & Cross-flow & ceramic & 1-5 bar & $95 \%$ & $\begin{array}{l}\text { Removal of } \mathrm{PO}_{4}{ }^{3-} \text { from domestic wastewater; Effects of surfactant nature } \\
\text { and concentration, } \mathrm{pH} \text { value, temperature, and trans-membrane pressure } \\
\text { on permeate flux and } \mathrm{PO}_{4}^{3-} \text { removal. }\end{array}$ & 2009 & [72] \\
\hline phosphate & CPC, ODA & $\begin{array}{l}4,30,50 \\
\mathrm{kDa}\end{array}$ & Dead-end & PES & $\begin{array}{l}0.1-0.2 \mathrm{Mpa} \\
(1-2 \text { bar })\end{array}$ & $95 \%$ & $\begin{array}{l}\text { The effects of surfactant type and concentration, membrane MWCO, and } \\
\text { trans-membrane pressure; Flux change during the MEUF process. }\end{array}$ & 2013 & [73] \\
\hline $\begin{array}{l}\mathrm{NO}_{3}^{-} \text {and } \\
\text { phosphate }\end{array}$ & CTAB & $\begin{array}{l}5,10,30 \\
\mathrm{kDa}\end{array}$ & Dead-end & cellulose & $\begin{array}{l}0.1-0.2 \mathrm{Mpa} \\
(1-2 \text { bar })\end{array}$ & $\begin{array}{l}73-91 \% \text { of } \\
\mathrm{NO}_{3}^{-} ; \\
11-34 \% \text { of } \\
\text { phosphate }\end{array}$ & $\begin{array}{l}\text { The effects of surfactant concentration, membrane } \mathrm{MWCO} \text {, and pressure on } \\
\text { permeate flux trans-membrane pressure and removal. }\end{array}$ & 2015 & [74] \\
\hline $\begin{array}{l}\mathrm{NO}_{3}^{-} \text {and } \\
\text { phosphate }\end{array}$ & CTAB, CPC & $5 \mathrm{kDa}$ & Dead-end & cellulose & $\begin{array}{l}60 \mathrm{psi} \\
(\sim 4 \text { bar })\end{array}$ & $\begin{array}{l}84 \% \text { of } \mathrm{NO}_{3} ; \\
91 \% \text { of } \\
\text { phosphate }\end{array}$ & $\begin{array}{l}\text { Determination of selectivity of common anions including } \mathrm{NO}_{3}^{-}, \mathrm{H}_{2} \mathrm{PO}_{4}^{-} \text {, and } \\
\mathrm{HPO}_{4}{ }^{2-} \text { to } \mathrm{CPC} \text { and } \mathrm{CTAB} \text {; Prediction model for nutrients removal from } \\
\text { water. }\end{array}$ & 2017 & [62] \\
\hline phosphate & QACLE & $\begin{array}{l}1.2-1.4 \\
\mathrm{kDa}\end{array}$ & Dialysis & / & $\begin{array}{l}\text { Concentration } \\
\text { gradient }\end{array}$ & $22.1-66.7 \%$ & Competition of common anions to $\mathrm{PO}_{4}{ }^{3-}$, and $\mathrm{pH}$ effect. & 2018 & [75] \\
\hline As (V) & CPC & $5,10 \mathrm{kDa}$ & Dead-end & $\begin{array}{l}\text { Cellulose; } \\
\text { PES }\end{array}$ & $\begin{array}{l}414 \mathrm{kPa} \\
\text { (4.14 bar) }\end{array}$ & Up to $100 \%$ & $\begin{array}{l}\text { The effects of membrane material, membrane MWCO, surfactant } \\
\text { concentration, and pH on the removal. }\end{array}$ & 2004 & [76] \\
\hline As (V) & $\mathrm{CPC}$ & $5 \mathrm{kDa}$ & Dead-end & PES & $\begin{array}{l}414 \mathrm{kPa} \\
(4.14 \mathrm{bar})\end{array}$ & $78.1-100 \%$ & $\begin{array}{l}\text { The effects of co-occurring inorganic solutes and As concentrations on As } \\
\text { removal and UF flux; Surfactant loss in permeate; As removal from well } \\
\text { water. }\end{array}$ & 2005 & [77] \\
\hline As (V) & CPC & $\begin{array}{l}\text { Pore size } \\
20-50 \mathrm{~nm}\end{array}$ & Cross-flow & ceramic & $\begin{array}{l}185 \mathrm{kPa} \\
\text { (1.85 bar) }\end{array}$ & $\sim 90 \%$ & $\begin{array}{l}\text { The effects of membrane pore size, trans-membrane pressure, } \mathrm{pH} \text {, } \\
\text { surfactant concentration, and As concentration on permeate flux decline, } \\
\text { As and CPC rejections. }\end{array}$ & 2006 & [78] \\
\hline
\end{tabular}




\begin{tabular}{|c|c|c|c|c|c|c|c|c|c|}
\hline As (V) & CPC & $100 \mathrm{kDa}$ & Cross-flow & PES & $1.85 \mathrm{kPa}$ & $93-98 \%$ & $\begin{array}{l}\text { The effects of trans-membrane pressure, } \mathrm{pH}, \mathrm{CPC} \text { concentration, As } \\
\text { concentration and ionic strength on permeate flux, As and CPC rejections. }\end{array}$ & 2007 & [56] \\
\hline As (V) & $\begin{array}{l}\text { CPC, CTAB, } \\
\text { ODA, BC }\end{array}$ & $3,10 \mathrm{kDa}$ & Dead-end & cellulose & $\begin{array}{l}200 \mathrm{kPa}(2 \\
\text { bar) }\end{array}$ & $\begin{array}{l}96 \% \text { for } \mathrm{CPC} ; \\
94 \% \text { for } \\
\text { CTAB; } 80 \% \\
\text { for ODA; } \\
57 \% \text { for BC }\end{array}$ & $\begin{array}{l}\text { The effects of surfactant type, } \mathrm{pH}, \mathrm{co}-\text { occurring anions }\left(\mathrm{NO}_{3}{ }^{-} \text {and } \mathrm{PO}_{4}{ }^{3-}\right) \text {, and } \\
\text { membrane operation configurations on the removal. }\end{array}$ & 2007 & [66] \\
\hline As (V) & CPC & $10 \mathrm{kDa}$ & Dead-end & cellulose & $\begin{array}{l}30 \mathrm{psi}(\sim 2 \\
\text { bar) }\end{array}$ & $\begin{array}{l}91 \% \text { and } \\
84 \%\end{array}$ & $\begin{array}{l}\text { Selectivity of As (V) to CPC micelles; The effects of CPC concentration, } \\
\text { competing anions, and pH on the removal; Modeling As (V) distribution in } \\
\text { different phases. }\end{array}$ & 2018 & [79] \\
\hline As (V) & CTAB, CPC & $\begin{array}{l}\text { pore size } \\
27.18 \mathrm{~nm}\end{array}$ & Dead-end & PAN & $1 \mathrm{bar}$ & Up to $100 \%$ & $\begin{array}{l}\text { The effects of initial concentrations of } \mathrm{As}(\mathrm{V}) \text {, surfactants, } \mathrm{pH} \text {, membrane } \\
\text { thickness, and co-existing anions on the removal of As, surfactant rejection, } \\
\text { and permeate flux. }\end{array}$ & 2019 & [80] \\
\hline $\begin{array}{l}\text { As }(\mathrm{V}) \text { and } \\
\mathrm{NO}_{3}^{-}\end{array}$ & CPC & / & Dead-end & PAN & / & $\begin{array}{l}96.9 \% \text { of } \mathrm{As} \\
(\mathrm{V}) ; 90.5 \% \text { of } \\
\mathrm{NO}_{3}^{-}\end{array}$ & $\begin{array}{l}\text { The effects of surfactant concentration, solution } \mathrm{pH} \text {, and trans-membrane } \\
\text { pressure on the permeate flux, removal of } \mathrm{As}(\mathrm{V}) \text { and } \mathrm{NO}_{3}{ }^{-} \text {, and } \mathrm{CPC} \\
\text { rejection. }\end{array}$ & 2019 & [81] \\
\hline As (V) & CPC & $10 \mathrm{kDa}$ & Cross-flow & PAN & 1.5-2.5 bar & Up to $99 \%$ & $\begin{array}{l}\text { Application of artificial neural network (ANN) to predict the optimum } \\
\text { operational conditions, including time, pressure, molar ratio of CPC to As, } \\
\text { concentration of As and pH of feed solution. }\end{array}$ & 2020 & [82] \\
\hline $\mathrm{CrO}_{4}{ }^{2-}$ & CTAC & $5 \mathrm{kDa}$ & Dead-end & $\begin{array}{l}\text { cellulose } \\
\text { acetate }\end{array}$ & $\begin{array}{l}414 \mathrm{kPa} \\
(4.14 \mathrm{bar})\end{array}$ & $>99.9 \%$ & $\begin{array}{l}\text { Modeling } \mathrm{CrO}_{4}^{2-} \text { binding with } \mathrm{CPC} \text { with or without added } \mathrm{NaCl} \text { via MEUF and } \\
\text { dialysis. }\end{array}$ & 1988 & [83] \\
\hline $\mathrm{CrO}_{4}{ }^{2-}$ & CTAB & $\begin{array}{l}\text { Pore size } \\
0.2 \mu \mathrm{m}\end{array}$ & Cross-flow & $\begin{array}{l}\text { cellulose } \\
\text { acetate }\end{array}$ & $\begin{array}{l}150 \mathrm{kPa} \\
(1.5 \mathrm{bar})\end{array}$ & Up to $>95 \%$ & $\begin{array}{l}\text { The effects of } \mathrm{CTAB} / \mathrm{ch} \text { romate concentration ratio at a constant } \\
\text { trans-membrane pressure and } \mathrm{pH} \text { of the feed solution. }\end{array}$ & 1997 & [84] \\
\hline $\mathrm{CrO}_{4}{ }^{2-}$ & CPC, CTAB & $10 \mathrm{kDa}$ & $\begin{array}{l}\text { tangential } \\
\text { cell }\end{array}$ & PS & 1-3 bar & Up to $>99 \%$ & $\begin{array}{l}\text { The effects of surfactant type, solution } \mathrm{pH} \text {, and ionic strength on the } \\
\text { removal. }\end{array}$ & 2001 & [85] \\
\hline $\begin{array}{l}\mathrm{CrO}_{4}{ }^{2-} \text { and } \\
\mathrm{NO}_{3}^{-}\end{array}$ & CPC & $3,10 \mathrm{kDa}$ & Dead-end & cellulose & 2 bar & $\begin{array}{l}80 \% \text { of } \mathrm{NO}_{3} \\
98 \% \text { of } \\
\mathrm{CrO}_{4}^{2-}\end{array}$ & $\begin{array}{l}\text { The effects of molar ratio of surfactants to pollutants and the membrane } \\
\text { MWCO. }\end{array}$ & 2004 & [86] \\
\hline $\begin{array}{l}\mathrm{CrO}_{4}^{2-} \text { and } \\
\mathrm{NO}_{3}^{-}\end{array}$ & CPC & $8 \mathrm{kDa}$ & cross-flow & PES & 2 bar & $\begin{array}{l}91 \% \text { of } \mathrm{NO}_{3}^{-} \\
>99 \% \text { of } \\
\mathrm{CrO}_{4}^{2-}\end{array}$ & The effects of molar ratio of surfactants to pollutants on the removal. & 2004 & [87] \\
\hline $\mathrm{CrO}_{4}{ }^{2-}$ & CTAB, CPC & $20 \mathrm{kDa}$ & Dead-end & PS & $\begin{array}{l}400 \mathrm{kPa} \\
(4 \mathrm{bar})\end{array}$ & $\begin{array}{l}99 \% ; 80 \% \\
\text { with added } \\
\mathrm{NaCl}\end{array}$ & $\begin{array}{l}\text { The effects of surfactant type and concentration, feed } \mathrm{Cr} \text { concentration, salt } \\
\text { concentration, solution } \mathrm{pH} \text {, pressure and temperature. }\end{array}$ & 2005 & [88] \\
\hline $\mathrm{CrO}_{4}{ }^{2-}$ & CPC & $10 \mathrm{kDa}$ & Dead-end & PES & $\begin{array}{l}376,580 \text { and } \\
716 \mathrm{kPa}\end{array}$ & Up to $>95 \%$ & $\begin{array}{l}\text { The effects of surfactant concentration, } \mathrm{Cr} \text { concentration, and pressure on } \\
\text { the removal. }\end{array}$ & 2006 & [89] \\
\hline
\end{tabular}




\begin{tabular}{|c|c|c|c|c|c|c|c|c|c|}
\hline $\begin{array}{l}\mathrm{Cr}(\mathrm{VI}) \text { and } \\
\mathrm{Cr}(\mathrm{III})\end{array}$ & $\begin{array}{l}\text { Rhamnolipi } \\
\text { d (JBR425) }\end{array}$ & $10 \mathrm{kDa}$ & Cross-flow & PS & / & Up to $96.2 \%$ & $\begin{array}{l}\text { A type of bio-surfactant was used; The effects of initial concentration of } \mathrm{Cr} \text {, } \\
\mathrm{pH} \text {, and surfactant concentration on the removal. }\end{array}$ & 2014 & [90] \\
\hline $\mathrm{CrO}_{4}{ }^{2-}$ & QACLE & $5 \mathrm{kDa}$ & Dead-end & cellulose & $\begin{array}{l}60 \mathrm{psi} \\
(\sim 4 \mathrm{bar})\end{array}$ & $95.9 \%$ & $\begin{array}{l}\text { Selectivity of } \mathrm{CrO}_{4}{ }^{2-} \text { to QACLE micelles; The effect of surfactant } \\
\text { concentration. }\end{array}$ & 2017 & [27] \\
\hline $\begin{array}{l}\mathrm{Fe}(\mathrm{CN}) 6^{3-} \\
\text { and } \mathrm{NO}_{3}^{-}\end{array}$ & CPC & $3,10 \mathrm{kDa}$ & Dead-end & cellulose & 2 bar & $\begin{array}{l}>99.9 \% \text { of } \\
\mathrm{Fe}(\mathrm{CN}) 6^{3-} \\
\text { and } 78 \% \text { of } \\
\mathrm{NO}_{3}{ }^{-} \text {at } \\
\text { molar ratio } \\
\text { of } 1: 1: 10 \\
\text { (CPC) }\end{array}$ & $\begin{array}{l}\text { Competing of } \mathrm{Fe}(\mathrm{CN}) 6^{3-} \text { and } \mathrm{NO}_{3}{ }^{-} \text {; The effect of surfactant to pollutants } \\
\text { concentration ratio. }\end{array}$ & 2003 & [91] \\
\hline $\begin{array}{l}\mathrm{Fe}(\mathrm{CN}) 6^{3-} \\
\text { and } \mathrm{CrO}_{4}{ }^{2-}\end{array}$ & ODA & $3,10 \mathrm{kDa}$ & Dead-end & cellulose & 2 bar & $\begin{array}{l}98 \% \text { of } \\
\mathrm{Fe}(\mathrm{CN}) 6^{3-} \\
\text { and }>99.9 \% \\
\text { of } \mathrm{CrO} 4^{2-} \text { at } \\
\text { molar ratio } \\
\text { of } 1: 1: 6 \\
\text { (ODA) }\end{array}$ & $\begin{array}{l}\text { Competing of } \mathrm{Fe}(\mathrm{CN}) 6^{3-} \text { and } \mathrm{CrO}_{4}{ }^{2-} \text {; The effect of surfactant to pollutants } \\
\text { concentration ratio. }\end{array}$ & 2003 & [92] \\
\hline $\mathrm{Fe}(\mathrm{CN}) 6^{3-}$ & CPC & $10 \mathrm{kDa}$ & Dead-end & cellulose & 4 bar & Up to $99.9 \%$ & $\begin{array}{l}\text { The effects of surfactant and ferricyanide concentration ratio on the } \\
\text { removal. }\end{array}$ & 2005 & [93] \\
\hline $\mathrm{PdCl}_{4}^{2-}$ & DTAC & $3 \mathrm{kDa}$ & Dead-end & cellulose & $\begin{array}{l}300 \mathrm{kPa} \\
(3 \mathrm{bar})\end{array}$ & $>95 \%$ & The effects of surfactant concentration and solution $\mathrm{pH}$ on the removal. & 2008 & [64] \\
\hline $\mathrm{ClO}^{-}$ & СТАВ & / & Cross-flow & $\begin{array}{l}\text { Self-made } \\
\text { PES with } \\
\mathrm{TiO}_{2}\end{array}$ & / & $75 \%$ & $\begin{array}{l}\text { The effects of various parameters including operating time, } \\
\text { trans-membrane pressure, CTAB concentration, } \mathrm{pH} \text { of feed solution, and } \\
\text { feed chlorine concentration on the MEUF process performance. }\end{array}$ & 2017 & [94] \\
\hline $\mathrm{F}^{-}$ & CPC, ODA & 4, $5 \mathrm{kDa}$ & Dead-end & $\begin{array}{l}\text { PES; } \\
\text { cellulose }\end{array}$ & $\begin{array}{l}0.2 \mathrm{MPa}(2 \\
\text { bar) }\end{array}$ & $\begin{array}{l}\text { Up to } 90 \% \\
\text { for CPC; up } \\
\text { to } 74 \% \text { for } \\
\text { ODA }\end{array}$ & $\begin{array}{l}\text { The effects of surfactant type, } F \text { concentration, surfactant concentration, } \\
\text { and salt concentration on the MEUF process performance. }\end{array}$ & 2018 & [95] \\
\hline
\end{tabular}




\subsubsection{Nutrients removal}

Phosphorus and nitrogen are essential nutrients for living organisms and play important roles in growth (i.e., synthesis of proteins, DNA, and RNA) and energy supply (i.e., energy transfer though adenosine triphosphate) of organisms [96]. However, the extensive use of phosphorus and nitrogenous compounds in industrial and agriculture activities often cause discharge of excess nutrients into natural waterbodies, which often results in eutrophication $[96,97]$. Effluent from municipal wastewater treatment plants and discharge from agricultural practices often contains high concentrations of phosphorus and nitrate that accelerates the rate of eutrophication $[98,99]$. Therefore, nutrient pollution control is critical to prevent eutrophication in many waterbodies, including major waterbodies such as Lake Erie in North America, and Lake Taihu in Eastern China. Nitrate and (poly- or ortho-) phosphate are the most common nutrients in natural waters. Researchers have focused on the removal of anionic nutrient species using cationic surfactant micelle assisted UF. Morel et al. [65] investigated $\mathrm{NO}_{3}{ }^{-}$removal using TTAB with UF (MWCO of 1 or $20 \mathrm{kDa}$ ), and reported that removal increased with an increase in surfactant concentration, and decreased with increasing MWCO. The MEUF efficiency was found to not depend on the initial nitrate concentration in the feed water, but was a function of the surfactant/nitrate concentration ratio, with up to $91 \%$ of $\mathrm{NO}_{3}{ }^{-}$removed using a $\mathrm{TTAB} / \mathrm{NO}_{3}{ }^{-}$concentration ratio of 5 across a 1 kDa membrane. It was postulated that TTAB monomers adsorbed onto the UF membrane played an important role in the separation process. Baek et al. [71] reported that phosphate removal during MEUF with CPC highly depended on $\mathrm{pH}$ because of the difference in o-phosphate species $\left(\mathrm{H}_{2} \mathrm{PO}_{4}^{-}, \mathrm{HPO}_{4}{ }^{2-}\right)$ concentrations as a function of solution $\mathrm{pH}$. At low $\mathrm{pH}$ $(<7)$, removal was lower than at the high $\mathrm{pH}(>7)$, because at low $\mathrm{pH}$ the monovalent phosphate species dominated. Camarillo et al. [72] employed ODA and CPC during MEUF to 
remove phosphate ions from treated domestic wastewaters, and found MEUF was able to achieve phosphate rejection $>99 \%$ at the optimal surfactant dosage. Beak et al. [70] and Kim et al. [60] studied mixed nutrient removal using MEUF. They observed both nitrate and phosphate were removed with high efficiency when a certain CPC concentration was applied, yet the permeate flux was reduced with increasing addition of CPC due to the gel layer formed on the surface of the membrane. Chen and Jafvert [62] investigated relative association affinities of common anions, including nitrate and phosphate, towards micelles formed with two common surfactants (CPC and CTAB) and developed a model to predict anions removal. They reported that up to $84 \%$ and $91 \%$ of $\mathrm{NO}_{3}{ }^{-}$and $\mathrm{HPO}_{4}{ }^{2-} / \mathrm{H}_{2} \mathrm{PO}_{4}{ }^{2-}$ respectively, were removed from natural surface water and nutrient-enriched water using MEUF (MWCO of $5 \mathrm{kDa}$ ), and removal was not as efficient using CTAB compared to CPC at the same molar concentrations due to the higher affinity of $\mathrm{Br}^{-}$for the micelles.

\subsubsection{Arsenic (V) removal}

Arsenic (As) in drinking water and food can seriously impact human health and environmental quality due to its bioaccumulation, high toxicity and carcinogenicity [100]. Arsenate $(A s(V))$ ions are generally the dominant inorganic arsenic species occurring in water under oxidizing conditions; Arsenite (As (III)) is the dominant species under reducing (anoxic) conditions. As (III) has a higher toxicity and is more difficult to eliminate from water than As (V), but is easily converted to As (V) by oxidation. Arsenate is a triprotic acid, so its speciation depends on $\mathrm{pH} . \quad \mathrm{H}_{2} \mathrm{AsO}_{4}{ }^{-}$and $\mathrm{HAsO}_{4}{ }^{2-}\left(p K_{a}=6.98\right)$ are the dominant anions in the $\mathrm{pH}$ range of $6-9$, which is the typical $\mathrm{pH}$ range of surface waters and groundwater [79]. Gecol et al. [76] investigated As (V) removal using UF membrane with and without CPC at varying $\mathrm{pH}$ values. They found the As removal and permeate flux depend on the membrane material, membrane MWCO, and water $\mathrm{pH}$. Arsenic (V) removal of $100 \%$ was achieved at As 
concentrations of 22 and $43 \mu \mathrm{g} / \mathrm{L}$ using a $5 \mathrm{kDa}$ PES membrane at $\mathrm{pH} 5.5$, and with a $10 \mathrm{kDa}$ membrane at $\mathrm{pH}$ of 8 . Iqbal et al. [66] compared the removal of $\mathrm{As}(\mathrm{V})$ using four types of surfactants, including $C P C, C T A B, O D A$, and $B C$, and the results indicated $C P C$ shows the highest removal efficiency, CTAB has a slightly lower removal efficiency, whereas BC has the lowest removal efficiency, largely due to its high $\mathrm{CMC}$ value. Removal was influenced by $\mathrm{pH}$ and competing anion concentration ( $\mathrm{NO}_{3}{ }^{-}$and o-phosphate). They also compared cross-flow and dead-end configurations, and the results indicated the decline in flux during cross-flow filtration was less than during dead-end filtration, but with comparable As removal. Ergican et al. [77] investigated As (V) removal from well water by MEUF with CPC, with co-occurring inorganic solutes, including $\mathrm{HCO}_{3}{ }^{-}, \mathrm{HPO}_{4}{ }^{2-}, \mathrm{H}_{4} \mathrm{SiO}_{4}$, and $\mathrm{SO}_{4}{ }^{2-}$ at $\mathrm{pH}$ 8. They report arsenic (at 0 to $105 \mu \mathrm{g} / \mathrm{L}$ in the feed water) removal significantly increased to between $78.1 \%$ to $100 \%$ with addition of $10 \mathrm{mM} \mathrm{CPC}$ to the feed water, and indicated removal was dependent on the concentrations of arsenic and co-occurring inorganic solutes in the feed water. Beolchini et al. $[56,78]$ reported that membranes with large pore sizes (ceramic membrane with pore sizes of 20 to $50 \mathrm{~nm}$, and $100 \mathrm{kDa}$ PES membranes) allow treatment of As-bearing solutions at high flux even when using low surfactant concentrations ( 1 to $3 \mathrm{mM}$ ). They observed surfactant leakage in the permeate at concentrations below the $\mathrm{CMC}$, indicating a potential effect of the concentration polarization layer. Chen et al. [79] investigated the relative selectivity of As (V) at different $\mathrm{pH}$ values, indicating the relative affinity sequence for binding of monovalent anions to CPC micelles as: $\mathrm{NO}_{3}{ }^{-}>\mathrm{Cl}^{-}>\mathrm{HCO}_{3}{ }^{-}>\mathrm{H}_{2} \mathrm{AsO}_{4}{ }^{-}$; and for divalent anions as: $\mathrm{SO}_{4}{ }^{2-}>\mathrm{HAsO}_{4}{ }^{2-}$. Based on selectivity coefficients and mass balance equations, a model was developed to predict As (V) distribution in the aqueous and the micellar phases. Bahmani et al. $[80,81]$ reported that micelles composed of CPC resulted in higher arsenic removal (91.7\%) compared to CTAB 
micelles (83.7\%), and an increasing removal of both $\mathrm{As}(\mathrm{V})$ and $\mathrm{NO}_{3}{ }^{-}$as the $\mathrm{CPC}$ concentration was increased, however with an associated decrease in permeate flux. Because of the acid-base chemistry of $\mathrm{As}(\mathrm{V})$, relative removal of $\mathrm{NO}_{3}{ }^{-}$versus $\mathrm{As}(\mathrm{V})$ is highly $\mathrm{pH}$ dependent, however under optimal conditions ( $\mathrm{CPC}$ concentration $=5 \mathrm{mM}, \mathrm{pH}=7$ to 8 , Pressure $=1$ bar), in a mixed solution more than $90 \%$ of both $\mathrm{As}(\mathrm{V})$ and $\mathrm{NO}_{3}{ }^{-}$can be removed by MEUF.

\subsubsection{Chromium (VI) removal}

Electroplating industries, leather tanning facilities, metal finishing industries, and nuclear power plants are heavy users of chromium salts and generate effluents containing chromium ( $\mathrm{Cr}$ ) ions. The stable oxidation states of $\mathrm{Cr}$ are $\mathrm{Cr}(\mathrm{III})$ and $\mathrm{Cr}(\mathrm{VI})$ in the natural environment. Whereas $\mathrm{Cr}(\mathrm{III})$ is an essential element for living beings, playing an important role in carbohydrate metabolism, $\mathrm{Cr}(\mathrm{VI})$ becomes carcinogenic under long exposure times, and shows 100 to 1000 folds higher toxicity than $\mathrm{Cr}$ (III) [101, 102]. $\mathrm{Cr}$ (VI) is the thermodynamically stable oxidation state in oxygen-rich environments, often present as chromate $\left(\mathrm{CrO}_{4}{ }^{2-}\right)$ or dichromate $\left(\mathrm{Cr}_{2} \mathrm{O}_{7}{ }^{2-}\right)$ in aqueous solutions. Considering the toxicity of $\mathrm{Cr}$ (VI), the US Environmental Protection Agency (EPA) determined the allowable amount of dischargeable $\mathrm{Cr}(\mathrm{VI})$ to surface water at below $50 \mu \mathrm{g} / \mathrm{L}$ [103]. Pollution of soil and groundwater by $\mathrm{Cr}(\mathrm{VI})$ is often a challenging environmental issue. $\mathrm{Cr}(\mathrm{VI})$ removal using MEUF has been studied widely since the 1980 s and research results indicate high Cr (VI) removal due to the high affinity of divalent $\mathrm{Cr}(\mathrm{VI})$ species to cationic surfactant micelles under natural water conditions. Christian et al. [83] investigated $\mathrm{CrO}_{4}{ }^{2-}$ equilibrium exchange with $\mathrm{Cl}^{-}$on CPC micelles across UF and dialysis membranes. The experimental results showed that very large selectivity for $\mathrm{CrO}_{4}{ }^{2-}$ was obtained, even in the presence of 0.05 to $0.10 \mathrm{M}$ $\mathrm{NaCl}$, with $\mathrm{CrO}_{4}{ }^{2-}$ permeate concentrations less than $0.1 \%$ compared to the original water 
concentration. Research results have shown that MEUF with CPC or CTAB can result in >99\% removal of $\mathrm{CrO}_{4}{ }^{2-}$ under optimal conditions of pressure, $\mathrm{pH}$, feed chromate and surfactant concentration. The rejection rate depends on ionic strength and $\mathrm{pH}$, with added $\mathrm{NaCl}$ reducing $\mathrm{Cr}(\mathrm{VI})$ rejection. However, even in the presence of $100 \mathrm{mM} \mathrm{NaCl}$, between 82 to $88 \%$ rejection still was achieved $[85,88]$. Similar to $A s(V)$, the rejection rate of chromate is highly dependent on the $\mathrm{pH}$ of the feed solution as $\mathrm{Cr}(\mathrm{VI})$ is present at different charges (i.e., valences) depending on $\mathrm{pH}[88]$. Beak and Yang $[86,87]$ investigated the simultaneous removal of $\mathrm{Cr}(\mathrm{VI})$ and $\mathrm{NO}_{3}{ }^{-}$, and have shown a larger affinity for $\mathrm{CrO}_{4}{ }^{2-}$ compared to $\mathrm{NO}_{3}{ }^{-}$for $\mathrm{CPC}$ micelles is due to the higher valence. Hence, at equal concentrations, nitrate removal is inhibited by the co-existence of chromate; however, with the proper surfactant/pollutant concentration ratio, both pollutants can be effectively removed (e.g., at a molar ratio of 1:1:10 (chromate: nitrate: surfactant), rejection of nitrate and chromate reached $80 \%$ and 98\%, respectively). Recently, some new types of surfactants have been employed for $\mathrm{Cr}$ (V) removal by MEUF. Abbasi-Garravand and Mulligan [90] applied a type of bio-surfactant (rhamnolipid, JBR 425) during MEUF for the removal of $\mathrm{Cr}(\mathrm{V})$ and $\mathrm{Cr}$ (III), and the results showed a maximum reduction in hexavalent chromium of $98.7 \%$ at an initial concentration of $10 \mathrm{mg} / \mathrm{L}$ at pH 6, and with a JBR 425 concentration of $2 \%$ (vol/vol). Chen et al. [27, 75] synthesized a new surfactant (QACLE) using conjugated linoleic acid and a quaternary ammonium salt, and showed that QACLE and CTAB both have higher selectivity for $\mathrm{CrO}_{4}{ }^{2-}$ over most common anions (e.g., $\mathrm{SO}_{4}{ }^{2-}, \mathrm{Cl}^{-}, \mathrm{NO}_{3}{ }^{-}$, and $\mathrm{HCO}_{3}{ }^{-}$) found in the natural waters. Up to $95.9 \%$ removal of $\mathrm{CrO}_{4}{ }^{2-}$ was achieved using $5 \mathrm{mM}$ QACLE self-assemble micelles.

\subsubsection{Cyanide removal}

Cyanide contains a triple bond between single carbon and nitrogen atoms, and since the $\mathrm{pK}_{\mathrm{a}}$ of hydrogen cyanide $(\mathrm{HCN})$ is approximately 9.2 , it exists in water predominately as the 
anionic species, $\mathrm{CN}^{-}$, at near neutral $\mathrm{pH}$ values. The most common source of cyanide contamination is former gas manufacturing sites. Yet, cyanide contamination is also associated with electroplating factories, gold mine tailings, road salt storage facilities, and other source of contamination [104]. Cyanide in groundwater in the presence of iron is tightly complexed to form ferricyanide or ferrocyanide. Ferricyanide $\left(\mathrm{Fe}(\mathrm{CN})_{6}{ }^{3-}\right)$ is an anthropogenic contaminant in soil and groundwater. Beak and Yang [93] reported high cyanide removal (up to $99 \%$ ) at a molar ratio of $\mathrm{CPC}$ to $\mathrm{Fe}(\mathrm{CN}) 6^{3-}$ of $3: 1$, at a $\mathrm{Fe}(\mathrm{CN})_{6}{ }^{3-}$ concentration of $1 \mathrm{mM}$, without competition from co-occurring anions. Beak et al. [91, 92] also studied simultaneous removal of several anions by MEUF, including $\mathrm{Fe}(\mathrm{CN})_{6}{ }^{3-}$, and have found that ferricyanide ions are more easily associated to the surfactant micelles than chromate or nitrate; however, simultaneous removal of chromate and nitrate can be achieved by increasing the surfactant concentration. Additional research reported the order of anion affinity to the cationic micelles decreases in the order: $\mathrm{Fe}(\mathrm{CN})_{6}{ }^{3-}>\mathrm{CrO}_{4}{ }^{2-}>\mathrm{NO}_{3}{ }^{-}$, with affinity clearly associated with ion charge (i.e., valence) [105].

\subsubsection{Other anion removal}

MEUF also has been studied to remove other inorganic anions from water. Ghezzi et al. [64] investigated removal of the precious metal, palladium (II) from water using DTAC, which exists predominately as $\mathrm{PdCl}_{4}{ }^{2-}$ in moderately saline water. The results indicated addition of DTAC at concentrations above the CMC results in $\mathrm{Pd}$ (II) removal exceeding 95\%; interestingly, the addition of a strong electrolyte (e.g., $\mathrm{MgCl}_{2}$ ) was useful in expelling the metal complex from the micelles, presumably due to competition from $\mathrm{Cl}^{-}$ions. Rahmati et al. [94] investigated the potential to use MEUF for the removal of free active chlorine (FAC) from synthetic wastewater using a polyethersulfone/titania (PES/TiO2) nano-composite membrane with assistance from CTAB. The results showed that the FAC rejection efficiency 
could be increased by increasing the nanoparticle concentration and by decreasing of $\mathrm{pH}$ and the feed chlorine concentration. It was shown that UF with PES/TiO2 nano-composite membranes had moderate retention of FAC under acidic conditions ( $\mathrm{pH}$ of 2 to 4), with rejection of about 75.0\%. Grzegorzek and Majewska-Nowak [95] applied MEUF for fluoride $\left(\mathrm{F}^{-}\right)$removal from aqueous solutions; the results indicated that for a $\mathrm{F}^{-}$concentration of 10 $\mathrm{mg} / \mathrm{L}$, and a high surfactant concentration ( 3 times the $\mathrm{CMC}$ ), a $\mathrm{F}^{-}$ion concentration in the permeate, below the permissible level for drinking water, could be achieved. The presence of $\mathrm{NaCl}$ in the aqueous solution resulted in a significant reduction of $\mathrm{F}^{-}$removal due to competition from $\mathrm{Cl}^{-}$for the micellar surface.

\section{Ion exchange on surfactant micelles}

Based on the results reported by previous researchers, MEUF conditions often can be controlled to achieve an optimum removal of target contaminants. Such operating conditions include: increasing the surfactant concentration, decreasing the membrane MWCO, and adjusting the trans-membrane pressure. Yet, co-occurring (competing) anions in the water adversely affect target anion removal during MEUF, and the competition from non-target anions often cannot be eliminated or neglected, as association is generally due to weak electrostatic (outer-sphere) association, rather than specific (inter-sphere) complexation (coordination). Indeed, wastewater and natural waters contain various anions of significant concentration, including $\mathrm{HCO}_{3}{ }^{-}, \mathrm{NO}_{3}{ }^{-}, \mathrm{SO}_{4}{ }^{2-}, \mathrm{Cl}^{-}$, and $\mathrm{HPO}_{4}{ }^{2-} / \mathrm{H}_{2} \mathrm{PO}_{4}{ }^{-}$, making removal efficiency a complex function of water ion composition, including hydrogen ion concentration. The surfactant micelles, however, can be treated as nano-sized ion exchange materials within the continuous aqueous phase, and the anions in the water form electrostatic bonds with the ionic surface of surfactant micelles, such that the distribution of 
anions between the micelle pseudo-phase and the surrounding continuous water phase depends on their relative affinity for the micelles and the total concentration of each ion in solution. Once the relative affinity (or selectivity) of each anion is known, this (thermodynamic) information can be used (alone with knowledge of the total concentration of each ion) to determine the distribution of all ions in solution; hence, the removal efficiency for each anion can be predicted via model calculation.

\subsection{Selectivity coefficients of anions for cationic surfactant micelles}

As nano-sized colloidal particles with electrical charge, ionic surfactant micelle association with counter-ions can be described by a triple-layer model $[106,107]$, shown in Figure 6. Surfactant molecules are the first layer, and the hydrated counter-ions closely associated with the surface of the micelle are considered the Stern layer (second layer). The diffuse layer (third layer) is between the Stern layer and the continuous solution phase, with a decrease in the electrical potential occurring through this layer, with also a decrease in the concentration of counter-ions also occurring within this layer. At the continuous phase boundary, the charge of the surfactant ions in the micelles is balanced by the charge of the counter-ions in the Stern and diffuse layers. Since ion association is often only through electrostatic interactions (i.e., outer-sphere complexation), it is not possible to distinguish the amount of surface charge that has been neutralized by Stern layer ions versus diffuse layer ions. Indeed, the distinction between these layers for outer-sphere complexation is simply a modeling exercise. 


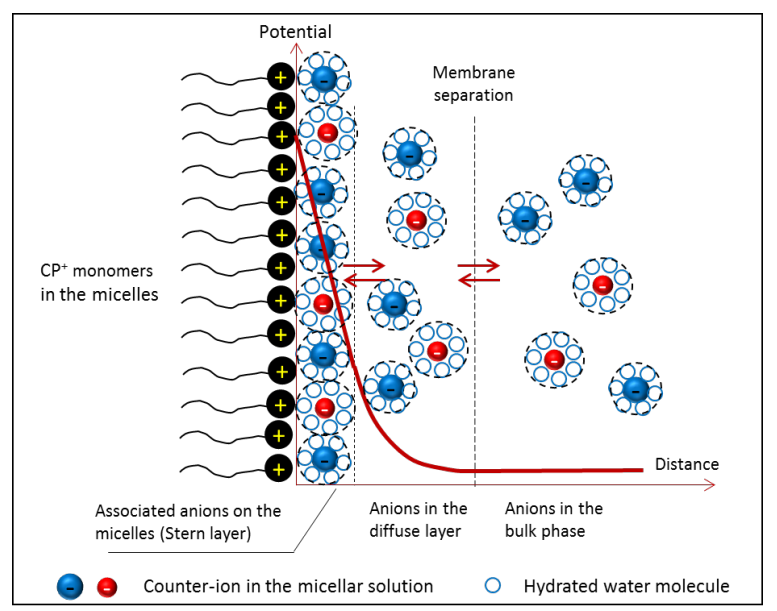

Figure 6. A triple-layer model for ions associated with a charged micelle surface [79]. Ion exchange models for resins have been reported widely [108-111], with the basic theory for ion exchange first developed by Helmholtz in 1879 [112]. To design a model for ion exchange, the equilibrium relationships for ions distributing between the resin and the solution phase need to be quantitatively and accurately captured. There are analogies between the interactions of counter-ions with ionic surfactant micelles and with ion exchange resins.

Fan et al. [113] and Miller [114] considered the micelle surface to have discrete exchange sites and defined the exchange of $\mathrm{Na}^{+}$with $\mathrm{Ca}^{2+}$ on anionic micelles through the following ion exchange-like equilibrium equation with equilibrium constant $\beta$,

$$
\beta=\frac{X_{C a}}{X_{N a}^{n}} \frac{\left[\mathrm{Na}^{+}\right]_{f}^{n}}{\left[\mathrm{Ca}^{2+}\right]_{f}}
$$

where $X_{C a}$ and $X_{N a}$ are the fractions of $\mathrm{Ca}^{2+}$ and $\mathrm{Na}^{+}$(in units of equivalence) in the micellar phase (per equivalent of surfactant), respectively; where the subscript $f$ denotes free aqueous solution ion molar concentrations; and $n(=2)$ is the substitution ratio of $\mathrm{Ca}^{2+}$ to $\mathrm{Na}^{+}$ on the micellar surface. With this equation, complete charge neutralization of the micelle is assumed $\left(X_{C a}+X_{N a}=1\right)$, and essentially the micelle and associating ions are considered as a double layer (as opposed to a triple layer model with separate Stern and diffuse layers). 
Chen and Jafvert $[62,75]$ have invoked a simple ion exchange model to describe anion exchange on the micelle surface, with the activity coefficients captured within the overall selectivity coefficients. Since it is assumed that the positive charge of each micelle is completely neutralized by associating anions, association of each ion is measured relative to the initial ion contained within the surfactant salt. The initial anions contained in the surfactant salt (e.g. $\mathrm{Br}^{-}$or $\mathrm{Cl}^{-}$) exchange with an anion added to the aqueous phase at micellar surfaces as represented by eq $\mathbf{2}$,

$\beta A_{m i c}^{\alpha-}+\alpha B_{a q}^{\beta-} \leftrightarrow \beta A_{a q}^{\alpha-}+\alpha B_{m i c}^{\beta-}$

where $A$ and $B$ represent the two different anions; $\alpha$ and $\beta$ refer to the valences of the anions $A$ and $B$, respectively; and the subscripts mic and $a q$ refer to micellar pseudo-phase and continuous aqueous phase, respectively. At equilibrium, the ion exchange equilibrium constant (selectivity coefficient) is defined as follows,

$K_{\text {sel }}=\frac{\left[A^{\alpha-}\right]_{a q}^{\beta}\left[B^{\beta-}\right]_{m i c}^{\alpha}}{\left[A^{\alpha-}\right]_{m i c}^{\beta}\left[B^{\beta-}\right]_{a q}^{\alpha}}$

Where $[\mathrm{i}]_{\mathrm{aq}}$ refers to the molar concentrations of the anions expressed in $\mathrm{mol} / \mathrm{L}$ in the aqueous phase; and [i] mic refers to the molar fraction of anions expressed in $\mathrm{mol} / \mathrm{mol}$ surfactant in the micellar phase. Molar fractions in the micellar phase are easily determined by UF separation experiments using either UF dialysis tubing or UF flat sheet membranes.

Based on the simple ion exchange model, the selectivity coefficients on aqueous micelles composed of either cetyltrimethylammonium $\left(\mathrm{CTA}^{+}\right)$bromide or cetylpyridinium $\left(\mathrm{CP}^{+}\right)$chloride towards many environmentally relevant anions, including $\mathrm{IO}_{3}^{-}, \mathrm{F}^{-}, \mathrm{Cl}^{-}, \mathrm{HCO}_{3}{ }^{-}$, $\mathrm{NO}_{2}^{-}, \mathrm{Br}^{-}, \mathrm{NO}_{3}{ }^{-}, \mathrm{H}_{2} \mathrm{PO}_{4}^{-}, \mathrm{HPO}_{4}{ }^{2-}, \mathrm{SO}_{4}{ }^{2-}$, and $\mathrm{CrO}_{4}{ }^{2-}$ were investigated in a series of UF experiments. Chen et al. [79] also studied the affinity of As (V) species at different pH values, and compared removal relative to $\mathrm{NO}_{3}{ }^{-}, \mathrm{SO}_{4}{ }^{2-}$, and $\mathrm{HCO}_{3}{ }^{-}$. Using the same ion exchange 
model, anion affinities for QACLE (quaternary ammonium hydroxypropyl conjugated linoleic acid ester) surfactant micelles or QASE (quaternary ammonium stearic acid ester) nanoparticles were investigated also using dialysis equilibrium experiments. Generally, a higher valence on the anion lead to a greater affinity for the micelle or nanoparticle; with the affinity decreasing as the hydrated radii of the anions increased among same-valence ions. Table $\mathbf{3}$ shows common selectivity coefficients (equation $\mathbf{3}$ ) on surfactant micelles with respect to $\mathrm{Cl}^{-}$. Because the selectivity coefficients only slightly vary among the different surfactant micelles for a given anion, the similarity of the affinities to each micelle is obvious. According to the previous studies concerning $\mathrm{Fe}(\mathrm{CN})_{6}{ }^{3-}$ and some other anions (including $\left.\mathrm{CrO}_{4}{ }^{2-}\right)$, the overall affinity of anions to $\mathrm{CTA}^{+}$or $\mathrm{CP}^{+}$surfactant micelles is expected to decrease in the following order: $\mathrm{Fe}(\mathrm{CN})_{6}{ }^{3-}>\mathrm{CrO}_{4}{ }^{2-}>\mathrm{SO}_{4}{ }^{2-}>\mathrm{HAsO}_{4}{ }^{2-}>\mathrm{HPO}_{4}{ }^{2-}>\mathrm{NO}_{3}{ }^{-}>\mathrm{Cl}^{-}>$ $\mathrm{HCO}_{3}^{-}>\mathrm{H}_{2} \mathrm{AsO}_{4}^{-}>\mathrm{H}_{2} \mathrm{PO}_{4}^{-}>\mathrm{F}^{-}>\mathrm{IO}_{3}^{-}$.

Table 3. Selectivity coefficients $\left(K_{\text {sel }}\right)$ for surfactant micelles with respect to $\mathrm{Cl}^{-}[27,62,75,79]$

\begin{tabular}{cccc}
\hline Anions & $\mathrm{CPC}$ & $\mathrm{CTAB}^{+}$ & QACLE \\
\hline $\mathrm{IO}_{3}{ }^{-}$ & $/$ & 0.45 & $/$ \\
$\mathrm{F}^{-}$ & 0.31 & 0.47 & 0.49 \\
$\mathrm{H}_{2} \mathrm{PO}_{4}^{-}$ & 0.32 & 0.47 & 0.53 \\
$\mathrm{H}_{2} \mathrm{AsO}^{4-}$ & 0.55 & $/$ & $/$ \\
$\mathrm{HCO}_{3}{ }^{-}$ & 0.60 & 0.70 & 0.89 \\
$\mathrm{Cl}^{-}$ & 1 & 1 & 1 \\
$\mathrm{NO}_{2}{ }^{-}$ & 1.27 & 1.43 & 1.20 \\
$\mathrm{Br}^{-}$ & 2.57 & 2.13 & 1.65 \\
$\mathrm{NO}_{3}{ }^{-}$ & 2.73 & 2.70 & 1.93 \\
$\mathrm{HPO}_{4}{ }^{2-\ddagger}$ & 0.030 & 0.026 & 0.035 \\
$\mathrm{HAsO}_{4}{ }^{2-}$ & 0.047 & $/$ & $/$ \\
$\mathrm{SO}_{4}{ }^{2-\ddagger}$ & 0.071 & 0.069 & 0.128 \\
$\mathrm{CrO}_{4}{ }^{2-}$ & $/$ & 0.196 & 0.368 \\
\hline
\end{tabular}

† Measured from ion exchange with $\mathrm{Br}^{-}$and then calculated relative to $\mathrm{Cl}^{-}$ $\ddagger$ unit of $\mathrm{L} / \mathrm{mol}$ 


\subsection{Anion distribution model in a micellar solution}

Once the equilibrium coefficient of an anion in the micellar solution is obtained via experimentation, a model composed of mass action (i.e., ion exchange), mass balance, and charge balance equations, can be developed to predict anion distribution and anion removal during MEUF. Christian et al. [83] first reported an equilibrium model to predict chromate distribution on CPC micelles, and the results showed a good correlation with ultrafiltration and equilibrium dialysis results. A similar method was reported for use in predicting the binding of arsenic anions to cationic micelles [115]. However, these studies focused on single anion system. A model that accounted for multi-ion distribution between the aqueous and micellar (or polymer) phase has been developed and verified in previous studies which can be used to predict target ion removal during UF $[62,79,116,117]$. The model was constructed based on all necessary mass action equations (i.e., selectivity coefficient equations), mass balance equations (i.e., on micellar surfactant and total ionic species concentrations), and any necessary acid-base reaction equations (i.e., to determine speciation of phosphate, arsenic, and/or chromate). The set of equations for calculating anion distribution in a micellar solution are listed in Table $\mathbf{4}$ (using CPC as the example surfactant), consistent with previous literature [79]. The total concentration of each anion in water is determined prior to the addition of a known concentration of surfactant into the water, $\left[\mathrm{A}_{i}^{\mathrm{n}}\right]_{\text {total, }}$ except for chloride, which is the sum of the initial $\mathrm{Cl}^{-}$concentration in the water and the chloride added with the surfactant salt. The $\mathrm{pH}$ of the sample is that measured after surfactant addition in order to properly calculate any anion concentration affected by acid dissociation, including $\mathrm{As}(\mathrm{V}), \mathrm{Cr}(\mathrm{VI})$, and phosphate species. In the model, 
unknown values (to be determined) are the concentrations of anions in the aqueous and micellar phases, i.e., $\left[\mathrm{A}_{i}{ }^{\mathrm{n}}\right]_{\text {aq }}$ and $\left[\mathrm{A}_{i}{ }^{\mathrm{n}}\right]_{\text {mic. }}$ Micellar surfactant concentration $(M)$ can be determined by knowing or measuring the $\mathrm{CMC}$ value, or at significantly high surfactant concentrations, can be assumed to equal the total concentration of surfactant added if the $\mathrm{CMC}$ is quite low. Because charge balance is assumed for each micelle, the total equivalent fraction of anions in the micellar pseudo-phase equals 1 (i.e., the same as the micellar surfactant concentration). Based on the selectivity coefficients of anions obtain from UF or dialysis experiments (discussed in Section 5.1), the equations of the model can be solved using "Solver" in Microsoft Excel to iteratively minimize the sum of squared errors on all mass balance equations by adjusting initial guesses on all unknown concentrations. This is accomplished by subtracting the left-hand-side of each mass balance equation from its respective right-hand-side, dividing by the left-hand side (to obtain a fractional error), and squaring the numerical result. These squared fractional errors are added to obtain the sum of squared errors, which when minimized by adjusting all unknown values results in the calculated ion distribution.

Table 4. Equations for calculating anion distribution in a micellar solution

\begin{tabular}{cc}
\hline & {$\left[\mathrm{Cl}^{-}\right]_{\text {total }}=[\mathrm{CPC}]_{\text {total }}+\left[\mathrm{Cl}^{-}\right]_{\text {initial }}$} \\
Mass & {$\left[A_{i}^{n-}\right]_{\text {total }}=\left[A_{i}^{n-}\right]_{a q}+\left[A_{i}^{n-}\right]_{\text {mic }} * M^{+}$} \\
balance & $\sum_{i} n\left[A_{i}^{n-}\right]_{\text {mic }}=1$ \\
\hline CMC & $M=[C P C]_{\text {total }}-C M C$ \\
calculation & \\
& $\operatorname{lnCMC}=\operatorname{aln}[Q]_{a q}+b$ \\
& {$[Q]_{a q}=\sum_{i}\left[A_{i}^{n-}\right]_{a q}$}
\end{tabular}




\begin{tabular}{cc}
\hline Mass action & $K_{\text {sel }}^{A_{C l^{-}}^{n-}}=\frac{\left[\mathrm{Cl}^{-}\right]_{a q}^{n}\left[A_{i}^{n-}\right]_{\text {mic }}}{\left[\mathrm{Cl}^{-}\right]_{\text {mic }}^{n}\left[A_{i}^{n-}\right]_{a q}}$ \\
\hline Species & $p H=-\log \left[H^{+}\right]$ \\
dependence & $K_{a}=\frac{\left[H^{+}\right]\left[A_{i}^{2-}\right]}{\left[A_{i}^{-}\right]}$ \\
\hline on pH & \\
\hline
\end{tabular}

${ }^{+} \mathrm{A}$ refers to each anion $i$ in the system, including $\mathrm{Cl}, \mathrm{Br}^{-}, \mathrm{F}^{-}, \mathrm{NO}_{2}^{-}, \mathrm{NO}_{3}^{-}, \mathrm{HCO}_{3}^{-}, \mathrm{SO}_{4}^{2-}, \mathrm{As}, \mathrm{Cr}$ and $\mathrm{P}$, while mass
balance equations for those species depended on $\mathrm{pH}$ are listed for the total mass. For example, $[\text { As }]_{\text {total }}=$
$\left[\mathrm{H}_{2} \mathrm{AsO}_{4}^{-}\right]_{a q}+\left[\mathrm{H}_{2} \mathrm{AsO}_{4}^{-}\right]_{\text {mic }} * M+\left[\mathrm{HAsO} \mathrm{O}_{4}^{2-}\right]_{a q}+\left[\mathrm{HAsO} \mathrm{H}_{4}^{2-}\right]_{\text {mic }} * M$
$\ddagger$ If the $\mathrm{CMC}$ of surfactant is quite low, the value of the $\mathrm{CMC}$ in the equations can be assumed to be negligible.

Figure 7 shows the iterative least squares scheme that can be used to solve the set of simultaneous algebraic equation (modified from the literature) [62], where o-phosphate removal using CPC micelles is taken as the example, with the co-occurring anions of $\mathrm{Cl}^{-}, \mathrm{F}^{-}$, $\mathrm{Br}^{-}, \mathrm{NO}_{3}{ }^{-}, \mathrm{HCO}_{3}{ }^{-}$, and $\mathrm{SO}_{4}{ }^{2-}$, and where the $\mathrm{CMC}$ is neglected (i.e., assumed negligible relative to the total surfactant concentration). To solve the system of simultaneous algebraic equations, first, the value of $[H]^{+}$is directly calculated from the $\mathrm{pH}$ value; because the $\mathrm{CMC}$ is assumed to be low in comparison to the total surfactant concentration, the value of $M$ is set equal to the total surfactant concentration; and finally, the total $\mathrm{Cl}^{-}$concentration is set equal to the sum of the concentration of CPC and any chloride initially present in the water. For this example case, there are 16 unknown values which are the aqueous and micellar anion concentrations. There are also 16 equations, which include the mass balance and mass action equations, which can be used to solve the unknown values. To further simplify the calculations (as shown in Figure 7), all species are calculated through an iterative process by making reasonable initial guesses on three species: $\left[\mathrm{Cl}^{-}\right]_{\mathrm{aq}},\left[\mathrm{SO}_{4}{ }^{2-}\right]_{\mathrm{aq}}$, and $\left[\mathrm{H}_{2} \mathrm{PO}_{4}{ }^{-}\right]_{\text {mic }}$. With a guess on $\left[\mathrm{Cl}^{-}\right]_{\mathrm{aq}}$, the value of $\left[\mathrm{Cl}^{-}\right]_{\text {mic }}$ is calculated, and from these two values, the aqueous 
and micellar concentrations of all monovalent anions are calculated $\left(\mathrm{F}^{-}, \mathrm{HCO}_{3}{ }^{-}, \mathrm{Br}^{-}\right.$and $\left.\mathrm{NO}_{3}{ }^{-}\right)$. With a guess on $\left[\mathrm{SO}_{4}{ }^{2-}\right]_{\mathrm{aq}}$, the value of $\left[\mathrm{SO}_{4}{ }^{2-}\right]_{\text {mic }}$ is calculated. With a guess on $\left[\mathrm{H}_{2} \mathrm{PO}_{4}{ }^{-}\right]_{\mathrm{mic}}$, the value of $\left[\mathrm{H}_{2} \mathrm{PO}_{4}{ }^{-}\right]_{\text {aq }}$ is calculated; the acid dissociation constant for $\mathrm{H}_{2} \mathrm{PO}_{4}{ }^{-}$is used to calculate $\left[\mathrm{HPO}_{4}{ }^{2-}\right]_{\mathrm{aq}}$, and from this value, the divalent phosphate on the micelles $\left(\left[\mathrm{HPO}_{4}{ }^{2-}\right]_{\mathrm{mic}}\right)$ is calculated. Based on the three guessed values, the model is simplified to three mass balance equations on phosphate, sulfate, and the total charge balance on the micelle phase. Therefore the normalized squares errors (between the right-hand-side and the left-hand-side of these three mass balance equations) are calculated, and added together to provide a sum of squared errors (SSE). The calculations are performed in Microsoft Excel, such that the built-in minimization algorithm "Solver" can be used to iteratively minimize the sum of squared errors by adjusting the initial guesses on $\left[\mathrm{Cl}^{-}\right]_{\mathrm{aq}},\left[\mathrm{SO}_{4}{ }^{2-}\right]_{\mathrm{aq}}$, and $\left[\mathrm{H}_{2} \mathrm{PO}_{4}{ }^{-}\right]_{\mathrm{mic}}$. Because Solver often assumes low values are negligible or close to zero, it is important to minimize errors on fractional (or percent) squared errors, and initial guesses to be adjusted should be the negative logarithms of concentrations (i.e., guess $\mathrm{p}\left[\mathrm{Cl}^{-}\right]=3$, and then immediately calculating $\left[\mathrm{Cl}^{-}\right]=0.001 \mathrm{M}$, such that the value of 3 is adjusted during iterations rather than 0.001 , as 0.001 may be sufficiently close to zero to discontinue the iterative process).

The model has been demonstrated to accurately converge to the anticipated solution under real MEUF conditions using both artificial and natural surface waters. Figure 8a, for example, shows predicted and experimental nutrient removal $\left(\mathrm{NO}_{3}{ }^{-}\right.$and $\left.\mathrm{PO}_{4}{ }^{3-}\right)$ using $\mathrm{CTAB}$ and $\mathrm{CPC}$, where the removal is defined by $1-\frac{\text { permeate concentration }}{\text { feed concentration }}$. The results show there is no significant difference between the model-calculated and 
experimentally-measured values. Figure $\mathbf{8} \mathbf{b}$ indicates good agreement between predicted and experimental aqueous concentrations of various anions in a cross-linked surfactant micelle solution after equilibrium during UF and dialysis processes. Figure $8 c$ shows the increase in As (V) removal as the concentration of CPC increased, and with good prediction of this increase by the model in an artificial mixed-ion solution. 


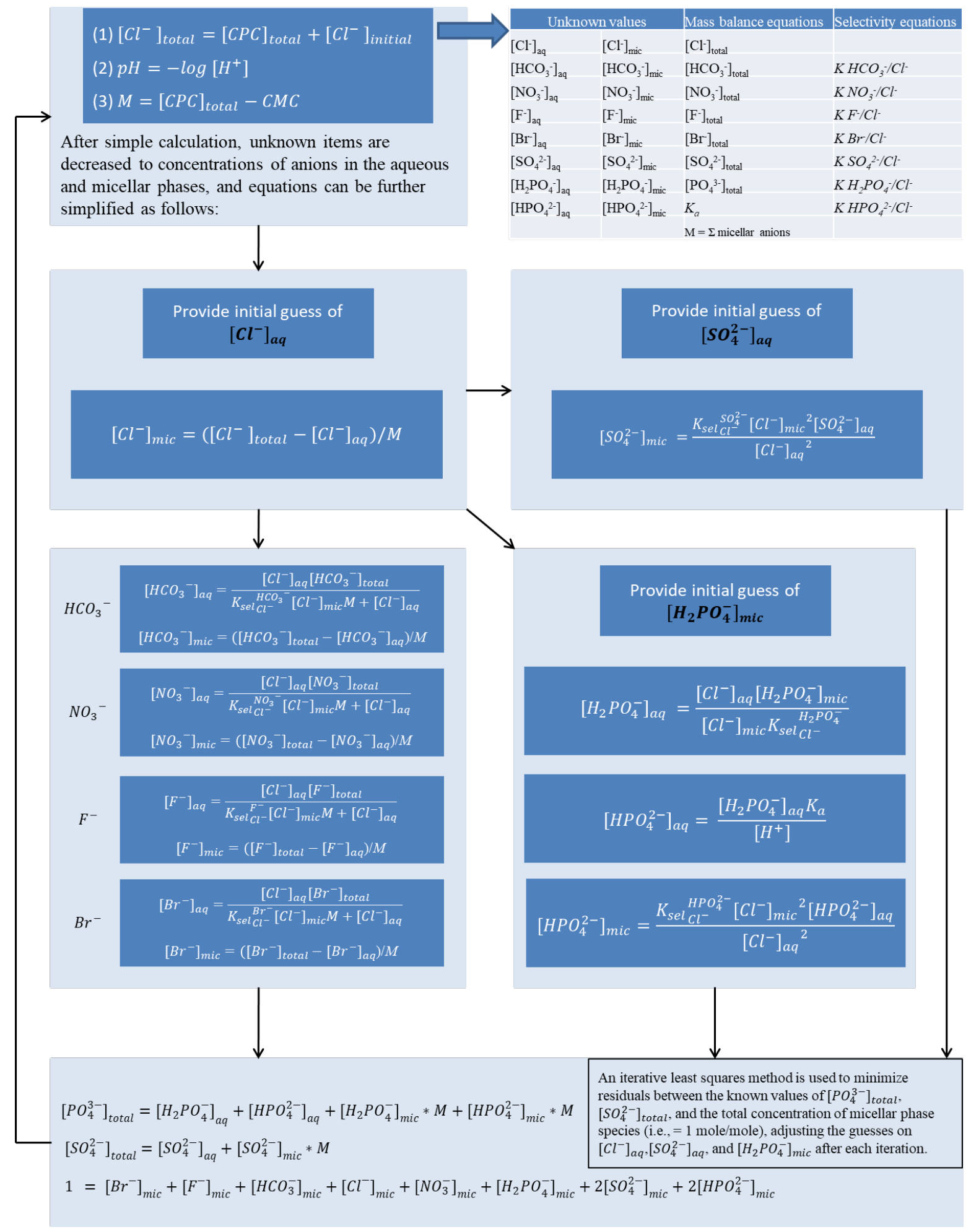

Figure 7. Calculation method for anion distribution in the aqueous and micellar phases

(modified base on the literature). 

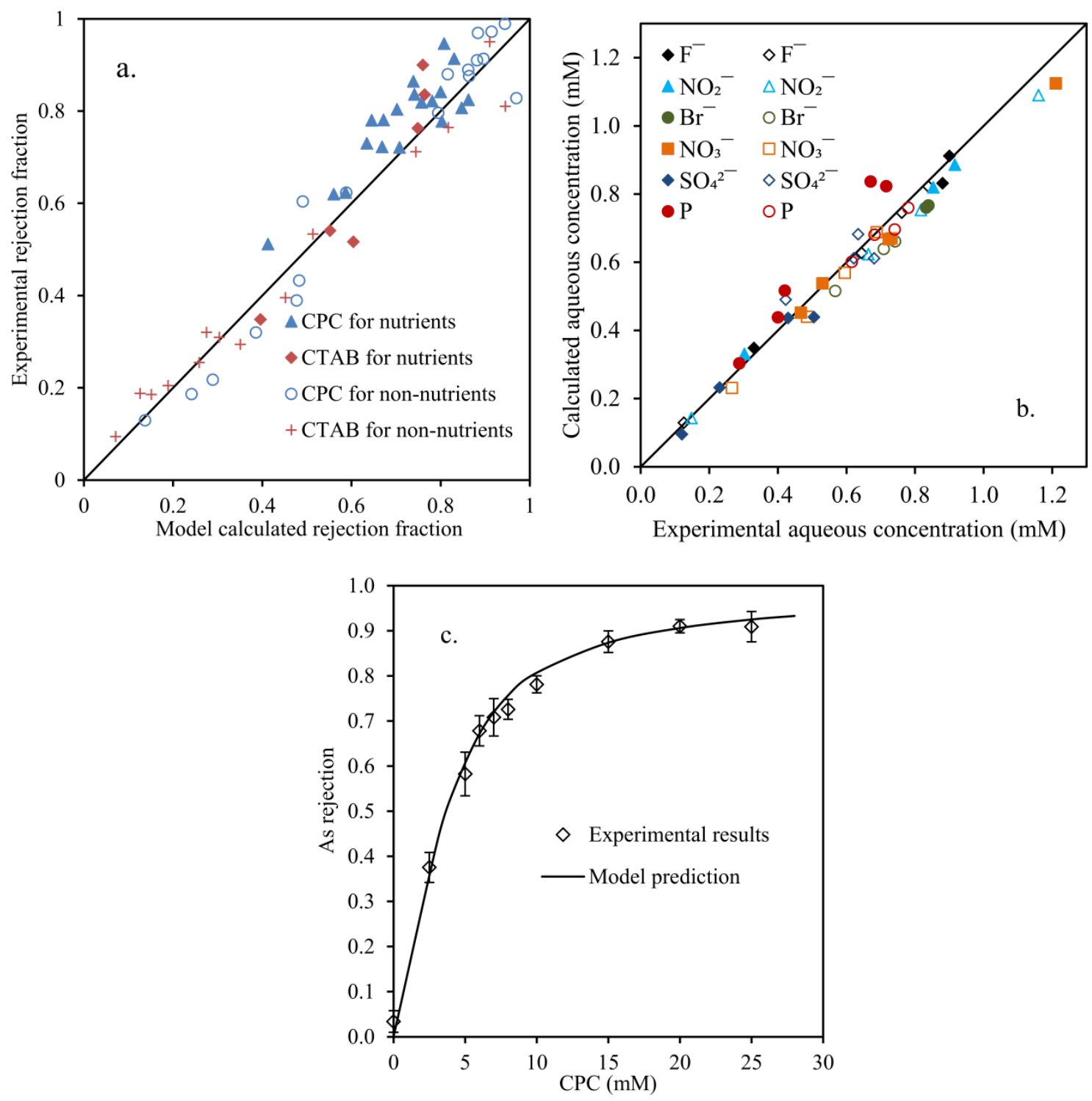

Figure 8. Model prediction for anion removal during MEUF: (a) Relationship between calculated and measured anion rejection fractions for the natural and nutrient-enriched waters with 5 to $10 \mathrm{mM} \mathrm{CPC}$ and CTAB [62]; (b) Relationship between measured aqueous concentrations and model predicted values in cross-linked QACLE solution (solid and open symbols are results from dialysis and UF experiments, respectively) [75]; (c) As (V) removal by CPC from artificial water samples with other anions present in solution [79].

\section{Suggested improvements in MEUF}


Surfactant micelles self-assemble, and if ion exchange occurs across a membrane, where the external water phase is flowing, significant loss of surfactant monomers (at a concentration equal to the $\mathrm{CMC}$ ) will occur over time through the UF membrane to an unacceptable level, and these surfactant monomers at concentrations up tens of milligrams per liter will be new organic pollutants in the permeate. For example, Baek et al. [70] have reported on monomeric $\mathrm{CPC}$ concentrations in the permeate at 0.7 to $0.75 \mathrm{mM}$ when they used a membrane with a MWCO between 3 to $10 \mathrm{kDa}$. In experiments conducted by Kim et al. [60], they reported that 1 to $3 \%$ of the CPC passed through the membrane, and they found the permeate CPC concentration increased as the MWCO of the membrane increasing. Several approaches have been investigated to resolve this issue, including applying mixed surfactants to decrease the $\mathrm{CMC}[118]$, utilizing adsorption methods on the permeate to remove the surfactant in the permeate [119], synthesizing cross-linked micelles [116], and using surfactant and polymer mixture, which forms colloidal aggregates [120]. A list of suggested improvements of MEUF is shown in Table 5.

Table 5. Suggested improvement methods for MEUF

\begin{tabular}{|c|c|c|}
\hline $\begin{array}{l}\text { Improvement } \\
\text { method }\end{array}$ & Example cases & Ref. \\
\hline \multirow{3}{*}{$\begin{array}{l}\text { Mixed surfactant } \\
\text { micelles }\end{array}$} & $\begin{array}{l}\text { Simultaneous removal of trichloroethylene and } \mathrm{Cr}(\mathrm{VI}) \text { by MEUF with } \\
\text { mixed micelles composed of CPC and Tween } 80 .\end{array}$ & [69] \\
\hline & $\begin{array}{l}\text { Removal of } \mathrm{Cr}(\mathrm{VI}) \text { using mixed surfactants (Tween-80 or Triton X-100 } \\
\text { and CTAB) during MEUF. }\end{array}$ & [121] \\
\hline & $\begin{array}{l}\text { Treatment of MEUF permeate with } 1 \mathrm{~g} / \mathrm{L} \text { powdered activated carbon, } \\
\text { with more than } 98 \% \text { removal of the surfactant. }\end{array}$ & {$[66]$} \\
\hline \multirow{2}{*}{$\begin{array}{l}\text { Combination of } \\
\text { MEUF and } \\
\text { adsorption }\end{array}$} & $\begin{array}{l}\text { Removal of } \mathrm{Cr}(\mathrm{VI}) \text { using } \mathrm{CTAB} \text { and powdered activated carbon (PAC) } \\
\text { together during cross-flow microfiltration, with } \mathrm{CTAB} \text { and chromate } \\
\text { rejections of } 91 \% \text { and } 97.2 \% \text {. }\end{array}$ & {$[122]$} \\
\hline & $\begin{array}{l}\text { Removal of } \mathrm{Cr}(\mathrm{VI}) \text { by MEUF followed by activated carbon fiber } \\
\text { treatment to remove CPC in the permeate, leaving only } 0.29 \mathrm{mg} / \mathrm{L} \mathrm{CPC} \\
\text { in the permeate. }\end{array}$ & [123] \\
\hline
\end{tabular}


A quaternary ammonium hydroxypropyl conjugated linoleic acid ester

Application of cationic surfactant (QACLE) was synthesized and cross-linked by UV-light in the presence of a photo-initiator. The cross-linked micelles cross-linked micelles have been used for chromate and phosphate removal across UF and dialysis membranes, without monomer loss.

Removals up to $99 \% \mathrm{Fe}(\mathrm{CN})_{6}{ }^{3-}$ and $80 \% \mathrm{CrO}_{4}{ }^{2-}$ were observed using

Polymer-surfactant aggregates (PSAs) PSAs consist of PAA and MTAB filtered through a $20 \mu \mathrm{m}$ coarse filter. The overall recycle process has shown that up to $94 \%$ of both $\mathrm{CrO}_{4}{ }^{2-}$ and the PAA-MTAB were recovered and were able to be reused, respectively, upon addition of $\mathrm{NaOH}$ and $\mathrm{H}_{2} \mathrm{SO}_{4}$ at optimal dosages.

\subsection{Mixed surfactant micelles}

As described above, the CMC value varies among surfactants as a function of molecular structure, with variation in head group size and charge, overall hydrophilicity of the head group, tail group length, and the hydrophobicity of tail group. Although lonic surfactants are suitable for removal of oppositely charged ions from aqueous solution by MEUF, the CMC of ionic surfactants is often rather large. Non-ionic surfactants normally have much lower CMC values [126], but cannot attract ions. The addition of a small amount of a non-ionic surfactant results in the formation of "mixed micelles" composed of non-ionic and ionic surfactants with an overall lower CMC value compared to the pure ionic surfactant system, due to reduced electrostatic repulsion of charged cationic head groups [127]. As a result, the residual surfactant monomers in the permeate decrease markedly. Lee et al. [69] have reported on simultaneous removal of trichloroethylene and chromate by MEUF with mixed micelles composed of CPC and Tween 80 surfactants. Tween 80 decreased the CMC of the surfactant mixture to below $0.2 \mathrm{mM}$ when the Tween 80 mole fraction was 0.2 . In order to decrease the CMC, Bielska and Szymanowski [128] studied mixtures of sodium dodecyl sulfate (SDS) added with an oxy-ethylated coconut fatty acid methyl ester to recover methylene blue from wastewater. The introduction of the non-ionic surfactant reduced the 
CMC from $8.3 \mathrm{mM}$ (of pure SDS in water) to $2.0 \mathrm{mM}$, at a mixture ratio of SDS to non-ionic surfactant of 4:1. Nura et al. [121] reported an effective removal of $\mathrm{Cr}(\mathrm{VI})$ by using mixed surfactants (non-ionic and cationic) during MEUF, with removal of chromate $(20 \mathrm{mg} / \mathrm{L}$ ) measured at $93 \%$ to $97 \%$ using 1.2 mM CTAB + Tween-80 or, CTAB + Triton X-100, respectively, at constant surfactant molar ratios of 0.1:1 (non-ionic : cationic). However, residual surfactant monomers remained in the UF permeate, and with increasing concentration of the non-ionic surfactant, the surface charge density of the micelles decreases, negatively influencing the removal efficiency of the target anions.

\subsection{Activated carbon adsorption combined with MEUF}

Regarding adsorption methods to remove the surfactant in the permeate, activated carbon has been shown to efficiently remove surfactant monomers from the permeate and is of widespread use among the adsorption materials in wastewater treatment practices [129]. Therefore, activated carbon adsorption could be used as a supplementary technology for controlling secondary pollution by the surfactants during MEUF [130]. In order to lower the concentration of the surfactant in the permeate during arsenate removal using MEUF, Iqbal et al. [66] treated the permeate with $1 \mathrm{~g} / \mathrm{L}$ powdered activated carbon before discharging to the environment, and more than $98 \%$ of the surfactant was removed by the PAC. Basar et al. [122] investigated the removal of chromate using CTAB and powdered activated carbon (PAC) together during cross-flow microfiltration, and the study showed that CTAB and chromate rejections of $91 \%$ and $97.2 \%$ were achieved, respectively, under conditions of $0.5 \mathrm{~g}$ PAC/L, $5 \mathrm{mM} \mathrm{CTAB}$, and $0.2 \mathrm{mM}$ chromate, with a 120 -minute processing time. Bade et al. [123] used MEUF to remove chromate followed by activated carbon fiber treatment to remove CPC in the permeate (at the molar ratio of chromate to CPC of 1:5), 
with $98.6 \%$ of the chromate removed across the membrane, and $99.9 \%$ of the CPC removed by the activated carbon, leaving only $0.29 \mathrm{mg} / \mathrm{L} \mathrm{CPC}$ in the permeate. Use of activated carbon, however, is expensive leading to much higher costs for overall water treatment.

\subsection{Cross-linking of surfactant micelles}

If the monomers within the micelles can be cross-linked, the new nano-sized colloid will be stable in suspension and loss of monomers across the membrane will not occur. A schematic of cross-linking surfactant micelles through reacting surfactants that contain double bonds is shown in Figure 9. Indeed, in recent years various new types of polymerizable amphiphilic molecules have been synthesized [131-134] and used in a variety of application, including for transport and release of pharmaceuticals $[135,136]$, as molecular templates [137], for making membranes for molecular-size based separations [138], and so on. Some researchers [139-141] have focused on environmental remediation by nano-sized polymerized amphiphilic molecules. Stable cross-linked micelles have the potential to be used to recover ions from water or wastewater when combined with UF or dialysis processes [116]. Chen et al. [27, 75] have synthesized a new quaternary ammonium hydroxypropyl conjugated linoleic acid ester cationic surfactant (QACLE) via reaction between conjugated linoleic acid (CLA) and (2,3-epoxypropyl)- trimethylammonium chloride (ETAC). QACLE has a similar quaternary ammonium head group structure as CTAB, but with conjugated double bonds in the tail group, making cross-linking possible under certain conditions. Because of the longer tail group, QACLE has a lower CMC value and large micellar size than those of CPC and CTAB. The selectivity coefficients of the QACLE micelles towards common anions in natural water are similar to those of CPC and CTAB. When present in aqueous micellar form, QACLE was cross-linked by UV-light in the presence of a 
photo-initiator, forming stable nanoparticles with high anion exchange capacity. After cross-linking, the surfactant will not be lost continuously during membrane separation processes as shown in Figure $\mathbf{9}$ where dialysis of both cross-linked and non-cross-linked (CPC) surfactant micelles is shown. The cross-linked micelles (or nanoparticles) have been used for chromate and phosphate removal across UF and dialysis membranes.
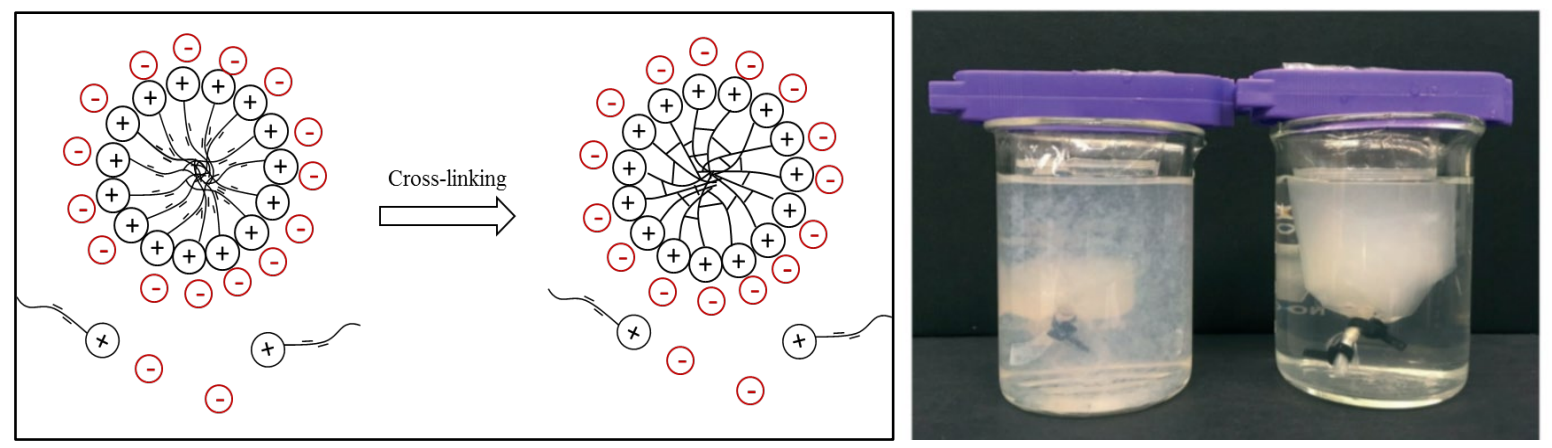

Figure 9. Cross-linked surfactant micelles: Schematic of cross-linking (left) with initiator and UV light; Dialysis of CPC micelles (left image), and QASE nanoparticles (right) with $\mathrm{K}_{2} \mathrm{~S}_{2} \mathrm{O}_{4}$ added to both the internal and external solution after $24 \mathrm{~h}$ (right photo) [75].

\subsection{Surfactant-polymer aggregate enhanced membrane separation}

Similar to surfactant micelle, water soluble polyelectrolyte can be used to improve membrane separation performance $[142,143]$. Based on studies of surfactant and polyelectrolyte systems, a novel heavy metal treatment process that uses polymer-surfactant aggregation has been developed, and has been shown to offer a promising approach to removal and recovery of valuable metal ions from water and wastewater [144-147]. This approach allows for the use of larger pore size membranes, such as microfiltration or coarse filtration membranes, because the size of the self-assembled "aggregates" is enlarged by addition of the polymer. Also, because the monomer concentration in the continuous water phase is lower than the typical CMC, reduced loss of material occurs during operation. Advantages include low operational costs, high treatment 
rate, and operational stability. The process uses oppositely charged polymer (or polyelectrolyte) and cationic surfactant to form aggregates referred to as polymersurfactant aggregates (PSAs) held together by purely electrostatic interactions. Because the aggregates differ from pure surfactant micelles, the activity of monomers (hence, the concentration) in the aqueous phase is lower than the $\mathrm{CMC}$ value of micelles composed of the same surfactant. PSAs formed by an anionic polymer and a cationic surfactant also have been developed for the removal and recovery of metallic anions (shown in Figure 10). Shen et al. [124] reported that anionic polymers, such as poly(sodium 4-styrenesulfonate) (PSS) or poly(acrylic acid) (PAA), can form a back-bone structure onto which cationic surfactants, such as MTAB, can form micelle-like aggregates. This results in larger flocculated aggregates with the ability to remove anions from solutions. The removals up to $99 \%$ $\mathrm{Fe}(\mathrm{CN})_{6}{ }^{3-}$ (initially at $\left.0.1 \mathrm{mM}\right)$ and $80 \% \mathrm{CrO}_{4}{ }^{2-}(0.2 \mathrm{mM})$ were observed using PSAs consist of PAA and MTAB filtered through a $20 \mu \mathrm{m}$ coarse filter. Research found that use of PSAs is effective for metallic anion removal over a pH range 4.5 to 6 and a temperature range of 5 to $50^{\circ} \mathrm{C}$. Furthermore, both salt and organic contaminants do not significantly interfere with anion removal. In addition, it was observed that using a cationic surfactant with a longer tail group facilitated the formation of PSAs and the removal of metallic anions [148]. Further research found adjustment of $\mathrm{pH}$ can result in greater recover the metallic anions from the flocculated PSAs into a concentrated solution, essentially recovering the polymer and surfactant for re-use. Results on the overall recycle process have shown that up to $94 \%$ of both $\mathrm{CrO}_{4}{ }^{2-}$ and the PAA-MTAB were recovered and were able to be reused, respectively, upon addition of $\mathrm{NaOH}$ and $\mathrm{H}_{2} \mathrm{SO}_{4}$ at optimal dosages [125]. 


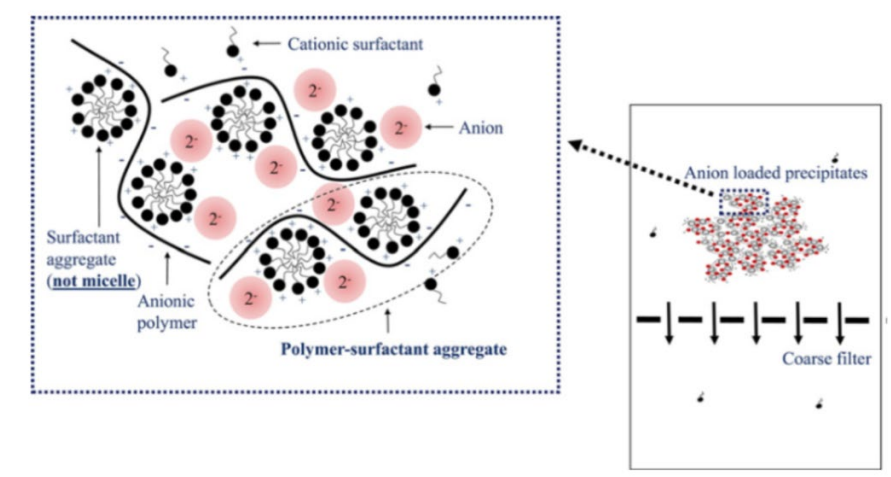

Figure 10. Removal of metallic anions from dilute aqueous solutions by polymersurfactant aggregates [124].

\section{Challenges and future opportunities of MEUF}

As shown in this review, MEUF is a promising strategy for the removal of anionic pollutants from aqueous solutions, with the advantages of high removal efficiency, low energy input, and rapid reaction. The state-of-the-art studies of MEUF have often focused on bench-scale MEUF tests. While there are some attempts at using MEUF for anion, metal or organic removal from real domestic and industrial wastewaters [72, 149-151], the process has not been adopted as a standard water treatment technique as of yet, and there is no reported industrial-scale water treatment plant applying MEUF. Some improvements have been employed to reduce the loss of surfactant monomers or to eliminate secondary pollution, as discussed in the above section; nevertheless, industrial scalability of this technique seems reasonable and can be positively expected if some key challenges can be properly overcome or addressed.

Without the reuse of surfactants, the MEUF operation will be costly and un-sustainable, because of the required continuous input of fresh surfactants to each batch of the feed solution. The increasing trend of efficiently recycling surfactants, valuable organics, and heavy metals from the MEUF retentate is inevitable. Although some studies have reported 
the recovery and recycle of surfactant, the required processes are still complicated. Purkait et al. $[50,51]$ reported a two-step chemical process to recover CPC from permeate and retentate, i.e., the precipitation of CPC using potassium iodide in the solution, followed by the addition of cupric chloride to recover CPC. Schwarze et al. [54] reported the recycle of surfactants by a temperature variation and using the cloud point phenomenon. However, studies on the efficient recycling of surfactants are still rare, especially for large-scale application. Thus, more attention should be paid to the feasible, economic and effective surfactant recovery strategies for industrial recyclability. Membrane flux is another key aspect for industrial applications. Although many factors, including operating pressure, solute concentration, membrane MWCO and surface area, and temperature may affect the flux, membrane fouling caused by surfactants will reduce the flux and membrane life markedly. Fouling-resistant UF membranes with minimum surfactant adsorption and efficient membrane cleaning methods are both therefore needed.

\section{Conclusions}

Surfactants have been studied extensively for the field of environmental remediation. Surfactant micelles have been used to enhance ultrafiltration separation performance for pollutants removal, with this process known as micellar enhance ultrafiltration (MEUF). When the concentration of ionic surfactants far exceeds the critical micellar concentration (CMC), a large concentration of micelles, consisting of tens to hundreds of monomers, will form in water as nano-sized ion exchanger. Assisted by ultrafiltration separation, pollutants associating with the micelles can be removed from natural waters or wastewaters. Metal cation removal using MEUF has been studied extensively and is well-reviewed in the literature. This review has focused on the removal of anions using MEUF. Anions of 
significance include nutrient species (nitrate and o-phosphate), arsenic chromium species, cyanide, and other anions (e.g., $\mathrm{F}^{-}$and metal complexes). Factors that influence MEUF performance include operating conditions (i.e., operating pressure, membrane pore size, $\mathrm{pH}$, competing ion concentrations), and the properties of the specific surfactant used during separation (i.e., chain length, $\mathrm{CMC}$, head group). Because different anions compete for association with the micellar phase, relative affinity (i.e., selectivity) for the micellar phase in multi-ion systems was reviewed. Based on anion selectivity coefficients and the associated mass action and mass balance equations, a simple model has been presented that can quantitatively predict anion distribution and recovery during micellar-enhanced ultrafiltration processes. Because loss of surfactant monomers during MEUF is an issue, ways of reducing this loss have been summarized, including: the application of mixed surfactant micelles to reduce the CMC, the combination of MEUF with activated carbon adsorption, the use of cross-linked micelles, and the combination of polymers with the surfactants to generate aggregates of larger size, also resulting in lower aqueous phase surfactant monomer concentrations. We expect that over the next few decades, these technologies will be more commonly adapted in industrial and environmental applications to remove anionic contaminants from aqueous water streams.

\section{Acknowledgement}

We acknowledge and thank the support from "Zhishan" Young Scholar Programs (A) of Southeast University to $M$. Chen.

\section{References}

[1] C.C. West, J.H. Harwell, Surfactants and subsurface remediation, Environmental Science \& Technology, 26 
(1992) 2324-2330.

[2] J.H. Harwell, D.A. Sabatini, R. Knox, Surfactants for ground water remediation, Colloids and Surfaces A: Physicochemical and Engineering Aspects, 151 (1999) 255-268.

[3] K. Urum, T. Pekdemir, M. Çopur, Surfactants treatment of crude oil contaminated soils, Journal of Colloid and interface Science, 276 (2004) 456-464.

[4] S. Iglauer, Y. Wu, P. Shuler, Y. Tang, W.A. Goddard III, New surfactant classes for enhanced oil recovery and their tertiary oil recovery potential, Journal of Petroleum Science and Engineering, 71 (2010) 23-29.

[5] D.O. Shah, Improved oil recovery by surfactant and polymer flooding, Elsevier, 2012.

[6] P. Raffa, A.A. Broekhuis, F. Picchioni, Polymeric surfactants for enhanced oil recovery: A review, Journal of Petroleum Science and Engineering, 145 (2016) 723-733.

[7] J. Wagner, H. Chen, B.J. Brownawell, J.C. Westall, Use of cationic surfactants to modify soil surfaces to promote sorption and retard migration of hydrophobic organic compounds, Environmental science \& technology, 28 (1994) 231-237.

[8] Y. Xi, R.L. Frost, H. He, T. Kloprogge, T. Bostrom, Modification of Wyoming montmorillonite surfaces using a cationic surfactant, Langmuir, 21 (2005) 8675-8680.

[9] S. Liu, M. Chen, X. Cao, G. Li, D. Zhang, M. Li, N. Meng, J. Yin, B. Yan, Chromium (VI) removal from water using cetylpyridinium chloride (CPC)-modified montmorillonite, Separation and Purification Technology, 241 (2020) 116732.

[10] F. Xiao, B.-q. Yan, X.-y. Zou, X.-q. Cao, L. Dong, X.-j. Lyu, L. Li, J. Qiu, P. Chen, S.-g. Hu, Study on ionic liquid modified montmorillonite and molecular dynamics simulation, Colloids and Surfaces A: Physicochemical and Engineering Aspects, 587 (2020) 124311.

[11] G. Morel, N. Ouazzani, A. Graciaa, J. Lachaise, Surfactant modified ultrafiltration for nitrate ion removal, Journal of membrane science, 134 (1997) 47-57.

[12] F. Ferella, M. Prisciandaro, I. De Michelis, Removal of heavy metals by surfactant-enhanced ultrafiltration from wastewaters, Desalination, 207 (2007) 125-133.

[13] W. Zhan, Y. Shu, Y. Sheng, H. Zhu, Y. Guo, L. Wang, Y. Guo, J. Zhang, G. Lu, S. Dai, Surfactant - Assisted Stabilization of Au Colloids on Solids for Heterogeneous Catalysis, Angewandte Chemie International Edition, 56 (2017) 4494-4498.

[14] G. La Sorella, G. Strukul, A. Scarso, Recent advances in catalysis in micellar media, Green Chemistry, 17 (2015) 644-683.

[15] C.T. Jafvert, L.V.H. Patricia, J.K. Heath, Solubilization of non-polar compounds by non-ionic surfactant micelles, Water Research, 28 (1994) 1009-1017.

[16] M. Mishra, P. Muthuprasanna, K.S. Prabha, P.S. Rani, I.A. Satish, I.S. Ch, G. Arunachalam, S. Shalini, Basics and potential applications of surfactants-a review, International Journal of PharmTech Research, 1 (2009) 1354-1365.

[17] P. Kaur, T. Garg, G. Rath, R. Murthy, A.K. Goyal, Surfactant-based drug delivery systems for treating drug-resistant lung cancer, Drug delivery, 23 (2016) 717-728.

[18] R.O. Dunn Jr, J.F. Scamehorn, S.D. Christian, Use of micellar-enhanced ultrafiltration to remove dissolved organics from aqueous streams, Separation science and technology, 20 (1985) 257-284.

[19] R. Bade, S.H. Lee, A review of studies on micellar enhanced ultrafiltration for heavy metals removal from wastewater, J Water Sustain, 1 (2011) 85-102.

[20] A.A. Mungray, S.V. Kulkarni, A.K. Mungray, Removal of heavy metals from wastewater using micellar enhanced ultrafiltration technique: a review, Central European Journal of Chemistry, 10 (2012) 27-46. [21] S. De, S. Mondal, Micellar Enhanced Ultrafiltration: Fundamentals \& Applications, CRC press, 2012. 
[22] M. Schwarze, Micellar-enhanced ultrafiltration (MEUF)-state of the art, Environmental Science: Water Research \& Technology, 3 (2017) 598-624.

[23] M. Yaqub, S.H. Lee, Heavy metals removal from aqueous solution through micellar enhanced ultrafiltration: A review, Environmental Engineering Research, 24 (2018) 363-375.

[24] M.J. Rosen, J.T. Kunjappu, Surfactants and interfacial phenomena, John Wiley \& Sons, 2012.

[25] R. Zieliński, S. Ikeda, H. Nomura, S. Kato, Effect of temperature on micelle formation in aqueous solutions of alkyltrimethylammonium bromides, Journal of colloid and interface science, 129 (1989) 175-184.

[26] S. Mehta, K. Bhasin, R. Chauhan, S. Dham, Effect of temperature on critical micelle concentration and thermodynamic behavior of dodecyldimethylethylammonium bromide and dodecyltrimethylammonium chloride in aqueous media, Colloids and Surfaces A: Physicochemical and Engineering Aspects, 255 (2005) 153-157.

[27] M. Chen, Y. Wu, C.T. Jafvert, Synthesis of cross-linked cationic surfactant nanoparticles for removing anions from water, Environmental Science: Nano, 4 (2017) 1534-1543.

[28] E.N. Stasiuk, L.L. Schramm, The temperature dependence of the critical micelle concentrations of foam-forming surfactants, Journal of colloid and interface science, 178 (1996) 324-333.

[29] A. Pan, A.K. Rakshit, S.P. Moulik, Micellization thermodynamics and the nature of enthalpy-entropy compensation, Colloids and Surfaces A: Physicochemical and Engineering Aspects, 495 (2016) 248-254. [30] M.P. Vázquez-Tato, F. Meijide, J.A. Seijas, F. Fraga, J.V. Tato, Analysis of an old controversy: the compensation temperature for micellization of surfactants, Advances in colloid and interface science, 254 (2018) 94-98.

[31] N. Das, H. Cao, H. Kaiser, G.T. Warren, J.R. Gladden, P.E. Sokol, Shape and size of highly concentrated micelles in CTAB/NaSal solutions by Small Angle Neutron Scattering (SANS), Langmuir, 28 (2012) 11962-11968. [32] R. Nagarajan, E. Ruckenstein, Theory of surfactant self-assembly: a predictive molecular thermodynamic approach, Langmuir, 7 (1991) 2934-2969.

[33] D. Lombardo, M.A. Kiselev, S. Magazù, P. Calandra, Amphiphiles self-assembly: basic concepts and future perspectives of supramolecular approaches, Advances in Condensed Matter Physics (2015) 151683.

[34] R.O. Dunn Jr, J.F. Scamehorn, S.D. Christian, Concentration polarization effects in the use of micellar-enhanced ultrafiltration to remove dissolved organic pollutants from wastewater, Separation Science and Technology, 22 (1987) 763-789.

[35] L.L. Gibbs, J.F. Scamehorn, S.D. Christian, Removal of n-alcohols from aqueous streams using micellar-enhanced ultrafiltration, Journal of membrane science, 30 (1987) 67-74.

[36] J.W. McBain, W.J. Jenkins, CCLXXXI. - The ultra-filtration of soap solutions: sodium oleate and potassium laurate, Journal of the Chemical Society, Transactions, 121 (1922) 2325-2344.

[37] H. Schott, Ultrafiltration of Nonionic Detergent Solutions1, The Journal of Physical Chemistry, 68 (1964) 3612-3619.

[38] L. Yurlova, A. Kryvoruchko, B. Kornilovich, Removal of Ni (II) ions from wastewater by micellar-enhanced ultrafiltration, Desalination, 144 (2002) 255-260.

[39] R.-S. Juang, Y.-Y. Xu, C.-L. Chen, Separation and removal of metal ions from dilute solutions using micellar-enhanced ultrafiltration, Journal of Membrane Science, 218 (2003) 257-267.

[40] J.-h. Huang, G.-m. Zeng, Y.-y. Fang, Y.-h. Qu, X. Li, Removal of cadmium ions using micellar-enhanced ultrafiltration with mixed anionic-nonionic surfactants, Journal of Membrane Science, 326 (2009) 303-309.

[41] B. Tanhaei, M.P. Chenar, N. Saghatoleslami, M. Hesampour, T. Laakso, M. Kallioinen, M. Sillanpää, M. Mänttäri, Simultaneous removal of aniline and nickel from water by micellar-enhanced ultrafiltration with different molecular weight cut-off membranes, Separation and Purification Technology, 124 (2014) 26-35. 
[42] X. Li, G.-M. Zeng, J.-H. Huang, D.-M. Zhang, L.-J. Shi, S.-B. He, M. Ruan, Simultaneous removal of cadmium ions and phenol with MEUF using SDS and mixed surfactants, Desalination, 276 (2011) 136-141.

[43] A. Ahmad, S. Puasa, M. Zulkali, Micellar-enhanced ultrafiltration for removal of reactive dyes from an aqueous solution, Desalination, 191 (2006) 153-161.

[44] M. Purkait, S. DasGupta, S. De, Micellar enhanced ultrafiltration of eosin dye using hexadecyl pyridinium chloride, Journal of hazardous materials, 136 (2006) 972-977.

[45] N. Zaghbani, A. Hafiane, M. Dhahbi, Removal of Direct Blue 71 from wastewater using micellar enhanced ultrafiltration, Desalination and Water Treatment, 6 (2009) 204-210.

[46] G.-M. Zeng, K. Xu, J.-H. Huang, X. Li, Y.-Y. Fang, Y.-H. Qu, Micellar enhanced ultrafiltration of phenol in synthetic wastewater using polysulfone spiral membrane, Journal of Membrane Science, 310 (2008) 149-160. [47] W. Zhang, G. Huang, J. Wei, D. Yan, Gemini micellar enhanced ultrafiltration (GMEUF) process for the treatment of phenol wastewater, Desalination, 311 (2013) 31-36.

[48] F. Tortora, V. Innocenzi, M. Prisciandaro, F. Vegliò, G.M. Di Celso, Heavy metal removal from liquid wastes by using micellar-enhanced ultrafiltration, Water, Air, \& Soil Pollution, 227 (2016) 240.

[49] F. Tortora, V. Innocenzi, M. Prisciandaro, I. De Michelis, F. Vegliò, G. Mazziotti di Celso, Removal of tetramethyl ammonium hydroxide from synthetic liquid wastes of electronic industry through micellar enhanced ultrafiltration, Journal of Dispersion Science and Technology, 39 (2018) 207-213.

[50] M. Purkait, S. DasGupta, S. De, Removal of dye from wastewater using micellar-enhanced ultrafiltration and recovery of surfactant, Separation and purification Technology, 37 (2004) 81-92.

[51] M. Purkait, S. DasGupta, S. De, Separation of aromatic alcohols using micellar-enhanced ultrafiltration and recovery of surfactant, Journal of membrane science, 250 (2005) 47-59.

[52] B. Wu, S. Christian, J. Scamehorn, Recovery of surfactant from micellar-enhanced ultrafiltration using a precipitation process, in: Horizons 2000-aspects of colloid and interface science at the turn of the millenium, Springer, 1998, 60-73.

[53] X. Li, G.-M. Zeng, J.-H. Huang, C. Zhang, Y.-Y. Fang, Y.-H. Qu, F. Luo, D. Lin, H.-L. Liu, Recovery and reuse of surfactant SDS from a MEUF retentate containing $\mathrm{Cd} 2+$ or $\mathrm{Zn} 2+$ by ultrafiltration, Journal of Membrane Science, 337 (2009) 92-97.

[54] M. Schwarze, L. Chiappisi, S. Prévost, M. Gradzielski, Oleylethoxycarboxylate-An efficient surfactant for copper extraction and surfactant recycling via micellar enhanced ultrafiltration, Journal of colloid and interface science, 421 (2014) 184-190.

[55] J. Huang, F. Qi, G. Zeng, L. Shi, X. Li, Y. Gu, Y. Shi, Repeating recovery and reuse of SDS micelles from MEUF retentate containing $\mathrm{Cd} 2+$ by acidification UF, Colloids and Surfaces A: Physicochemical and Engineering Aspects, 520 (2017) 361-368.

[56] F. Beolchini, F. Pagnanelli, I. De Michelis, F. Vegliò, Treatment of concentrated arsenic (V) solutions by micellar enhanced ultrafiltration with high molecular weight cut-off membrane, Journal of hazardous materials, 148 (2007) 116-121.

[57] J. Huang, L. Liu, G. Zeng, X. Li, L. Peng, F. Li, Y. Jiang, Y. Zhao, X. Huang, Influence of feed concentration and transmembrane pressure on membrane fouling and effect of hydraulic flushing on the performance of ultrafiltration, Desalination, 335 (2014) 1-8.

[58] W. Zhang, W. Liang, G. Huang, J. Wei, L. Ding, M.Y. Jaffrin, Studies of membrane fouling mechanisms involved in the micellar-enhanced ultrafiltration using blocking models, RSC Advances, 5 (2015) 48484-48491. [59] X. Shi, G. Tal, N.P. Hankins, V. Gitis, Fouling and cleaning of ultrafiltration membranes: a review, Journal of Water Process Engineering, 1 (2014) 121-138.

[60] B.-K. Kim, K. Baek, J.-W. Yang, Simultaneous removal of nitrate and phosphate using cross-flow 
micellar-enhanced ultrafiltration (MEUF), Water Science and Technology, 50 (2004) 227-234.

[61] W. Koros, Y. Ma, T. Shimidzu, Terminology for membranes and membrane processes (IUPAC Recommendations 1996), Pure and Applied Chemistry, 68 (1996) 1479-1489.

[62] M. Chen, C.T. Jafvert, Anion exchange on cationic surfactant micelles, and a speciation model for estimating anion removal on micelles during ultrafiltration of water, Langmuir, 33 (2017) 6540-6549.

[63] M.F. Emerson, A. Holtzer, On the ionic strength dependence of micelle number. II, The Journal of physical chemistry, 71 (1967) 1898-1907.

[64] L. Ghezzi, B.H. Robinson, F. Secco, M.R. Tiné, M. Venturini, Removal and recovery of palladium(II) ions from water using micellar-enhanced ultrafiltration with a cationic surfactant, Colloids and Surfaces A:

Physicochemical and Engineering Aspects, 329 (2008) 12-17.

[65] G. Morel, A. Graciaa, J. Lachaise, Enhanced nitrate ultrafiltration by cationic surfactant, Journal of membrane science, 56 (1991) 1-12.

[66] J. Iqbal, H.J. Kim, J.S. Yang, K. Baek, J.W. Yang, Removal of arsenic from groundwater by micellar-enhanced ultrafiltration (MEUF), Chemosphere, 66 (2007) 970-976.

[67] C.H. Tan, Z.J. Huang, X.G. Huang, Rapid determination of surfactant critical micelle concentration in aqueous solutions using fiber-optic refractive index sensing, Analytical biochemistry, 401 (2010) 144-147. [68] J.-H. Huang, Y.-L. Xiong, G.-M. Zeng, S.-H. Guo, G.-X. Xie, D.-M. Zhang, X.-J. Tang, Z.-F. Liu, Separation of phenol from various micellar solutions using MEUF, Separation and Purification Technology, 98 (2012) 1-6. [69] J. Lee, J.-S. Yang, H.-J. Kim, K. Baek, J.-W. Yang, Simultaneous removal of organic and inorganic contaminants by micellar enhanced ultrafiltration with mixed surfactant, Desalination, 184 (2005) 395-407.

[70] K. Baek, B.-K. Kim, J.-W. Yang, Application of micellar enhanced ultrafiltration for nutrients removal, Desalination, 156 (2003) 137-144.

[71] K. Baek, B.-K. Kim, J.-W. Yang, Removal of phosphorous using micellar-enhanced ultrafiltration with cationic surfactant: Effects of surrounding pH, Fresenius Environmental Bulletin, 13 (2004) 105-111.

[72] R. Camarillo, I. Asencio, J. Rincón, Micellar Enhanced Ultrafiltration for phosphorus removal in domestic wastewater, Desalination and Water Treatment, 6 (2009) 211-216.

[73] J. Gorna, K. Majewska-Nowak, Surfactant enhanced ultrafiltration for the removal of inorganic phosphorous compounds from aqueous solutions, Environment Protection Engineering, 39 (2013) 197-206. [74] J. Górna, K. Majewska-Nowak, Removal of inorganic nitrogen and phosphorous compounds from two-component aqueous solutions by micellar enhanced ultrafiltration, Environment Protection Engineering, 41 (2015) 167-178.

[75] M. Chen, C.T. Jafvert, Anion recovery from water by cross-linked cationic surfactant nanoparticles across dialysis membranes, Environmental Science: Nano, 5 (2018) 1350-1360.

[76] H. Gecol, E. Ergican, A. Fuchs, Molecular level separation of arsenic (V) from water using cationic surfactant micelles and ultrafiltration membrane, Journal of membrane science, 241 (2004) 105-119.

[77] E. Ergican, H. Gecol, A. Fuchs, The effect of co-occurring inorganic solutes on the removal of arsenic (V) from water using cationic surfactant micelles and an ultrafiltration membrane, Desalination, 181 (2005) 9-26.

[78] F. Beolchini, F. Pagnanelli, I. De Michelis, F. Vegliò, Micellar enhanced ultrafiltration for arsenic (V) removal: effect of main operating conditions and dynamic modelling, Environmental science \& technology, 40 (2006) 2746-2752.

[79] M. Chen, K. Shafer-Peltier, S.J. Randtke, E. Peltier, Modeling arsenic (V) removal from water by micellar enhanced ultrafiltration in the presence of competing anions, Chemosphere, 213 (2018) 285-294.

[80] P. Bahmani, A. Maleki, R. Rezaee, A.H. Mahvi, M. Khamforoush, S. Dehestani Athar, H. Daraei, F. Gharibi, G. McKay, Arsenate removal from aqueous solutions using micellar-enhanced ultrafiltration, Journal of 
Environmental Health Science and Engineering, 17 (2019) 115-127.

[81] P. Bahmani, A. Maleki, R. Rezaee, M. Khamforoush, K. Yetilmezsoy, S. Dehestani Athar, F. Gharibi, Simultaneous removal of arsenate and nitrate from aqueous solutions using micellar-enhanced ultrafiltration process, Journal of Water Process Engineering, 27 (2019) 24-31.

[82] M. Yaqub, S.H. Lee, Experimental and neural network modeling of micellar enhanced ultrafiltration for arsenic removal from aqueous solution, Environmental Engineering Research, 26(1) (2021) 190261.

[83] S. Christian, S. Bhat, E. Tucker, J. Scamehorn, D. El - Sayed, Micellar - enhanced ultrafiltration of chromate anion from aqueous streams, AIChE journal, 34 (1988) 189-194.

[84] B. Keskinler, U. Danis, A. Cakici, G. Akay, Chromate removal from water using surfactant-enhanced crossflow filtration, Separation science and technology, 32 (1997) 1899-1920.

[85] L. Gzara, M. Dhahbi, Removal of chromate anions by micellar-enhanced ultrafiltration using cationic surfactants, Desalination, 137 (2001) 241-250.

[86] K. Baek, J.-W. Yang, Micellar-enhanced ultrafiltration of chromate and nitrate: binding competition between chromate and nitrate, Desalination, 167 (2004) 111-118.

[87] K. Baek, J.-W. Yang, Cross-flow micellar-enhanced ultrafiltration for removal of nitrate and chromate: competitive binding, Journal of hazardous materials, 108 (2004) 119-123.

[88] S.B. Kamble, K.V. Marathe, Membrane Characteristics and Fouling Study in MEUF for the Removal of Chromate Anions from Aqueous Streams, Separation Science and Technology, 40 (2005) 3051-3070.

[89] G. Ghosh, P.K. Bhattacharya, Hexavalent chromium ion removal through micellar enhanced ultrafiltration, Chemical Engineering Journal, 119 (2006) 45-53.

[90] E. Abbasi-Garravand, C.N. Mulligan, Using micellar enhanced ultrafiltration and reduction techniques for removal of $\mathrm{Cr}$ (VI) and $\mathrm{Cr}$ (III) from water, Separation and Purification Technology, 132 (2014) 505-512.

[91] K. Baek, H.-H. Lee, J.-W. Yang, Micellar-enhanced ultrafiltration for simultaneous removal of ferricyanide and nitrate, Desalination, 158 (2003) 157-166.

[92] K. Baek, B.-K. Kim, H.-J. Cho, J.-W. Yang, Removal characteristics of anionic metals by micellar-enhanced ultrafiltration, Journal of hazardous materials, 99 (2003) 303-311.

[93] K. Baek, J.W. Yang, Removal of ferriccyanide using micellar enhanced ultrafiltration (MEUF), Developments in Chemical Engineering and Mineral Processing, 13 (2005) 137-146.

[94] N.O. Rahmati, M. Pourafshari Chenar, H. Azizi Namaghi, Removal of free active chlorine from synthetic wastewater by MEUF process using polyethersulfone/titania nanocomposite membrane, Separation and Purification Technology, 181 (2017) 213-222.

[95] M. Grzegorzek, K. Majewska-Nowak, The use of micellar-enhanced ultrafiltration (MEUF) for fluoride removal from aqueous solutions, Separation and Purification Technology, 195 (2018) 1-11.

[96] D.J. Conley, H.W. Paerl, R.W. Howarth, D.F. Boesch, S.P. Seitzinger, K.E. Havens, C. Lancelot, G.E. Likens, Controlling eutrophication: nitrogen and phosphorus, in American Association for the Advancement of Science, 2009.

[97] D.W. Schindler, Recent advances in the understanding and management of eutrophication, Limnology and oceanography, 51 (2006) 356-363.

[98] J.T. Sims, R.R. Simard, B.C. Joern, Phosphorus loss in agricultural drainage: Historical perspective and current research, Journal of environmental quality, 27 (1998) 277-293.

[99] R.O. Carey, K.W. Migliaccio, Contribution of wastewater treatment plant effluents to nutrient dynamics in aquatic systems: a review, Environmental management, 44 (2009) 205-217.

[100] E.V. Bräuner, R.B. Nordsborg, Z.J. Andersen, A. Tjønneland, S. Loft, O. Raaschou-Nielsen, Long-term exposure to low-level arsenic in drinking water and diabetes incidence: a prospective study of the diet, cancer 
and health cohort, Environmental health perspectives, 122 (2014) 1059-1065.

[101] K. Cheung, J.-D. Gu, Mechanism of hexavalent chromium detoxification by microorganisms and bioremediation application potential: a review, International Biodeterioration \& Biodegradation, 59 (2007) 8-15.

[102] S. Mishra, R.N. Bharagava, Toxic and genotoxic effects of hexavalent chromium in environment and its bioremediation strategies, Journal of Environmental Science and Health, Part C, 34 (2016) 1-32.

[103] A. Baral, R.D. Engelken, Chromium-based regulations and greening in metal finishing industries in the USA, Environmental Science \& Policy, 5 (2002) 121-133.

[104] P. Kjeldsen, Behaviour of cyanides in soil and groundwater: a review, Water, Air, and Soil Pollution, 115 (1999) 279-308.

[105] K. Baek, J.-W. Yang, Effect of valences on removal of anionic pollutants using micellar-enhanced ultrafiltration, Desalination, 167 (2004) 119-125.

[106] J.F. Rathman, J.F. Scamehorn, Counterion binding on mixed micelles, The Journal of Physical Chemistry, 88 (1984) 5807-5816.

[107] C.-C. Lin, C.T. Jafvert, A triple layer, planar coordinate model for describing counterion association to micelles, Langmuir, 16 (2000) 2450-2456.

[108] J. Kim, M.M. Benjamin, Modeling a novel ion exchange process for arsenic and nitrate removal, Water research, 38 (2004) 2053-2062.

[109] S. Sodaye, G. Suresh, A.K. Pandey, A. Goswami, Determination and theoretical evaluation of selectivity coefficients of monovalent anions in anion-exchange polymer inclusion membrane, Journal of Membrane Science, 295 (2007) 108-113.

[110] J. Dron, A. Dodi, Thermodynamic modeling of $\mathrm{Cl}(-), \mathrm{NO} 3(-)$ and SO4(2-) removal by an anion exchange resin and comparison with Dubinin-Astakhov isotherms, Langmuir, 27 (2011) 2625-2633.

[111] F. Guesmi, C. Hannachi, B. Hamrouni, Modification of the AMX membrane surface: Temperature dependence of anion exchange equilibrium, The Canadian Journal of Chemical Engineering, 91 (2013) 1465-1473.

[112] H. Helmholtz, Studien über elektrische Grenzschichten, Annals of Physics, (1879) 337-382.

[113] X.-J. Fan, P. Stenius, N. Kallay, E. Matijević, Precipitation of surfactant salts: II. The effect of nonionic surfactants on precipitation of calcium dodecyl sulfate, Journal of colloid and interface science, 121 (1988) 571-578.

[114] D. Miller, Binding of calcium ions to micelles-a metallochromic indicator study, Colloid and Polymer Science, 267 (1989) 929-934.

[115] E. Ergican, H. Gecol, Nonlinear two-phase equilibrium model for the binding of arsenic anions to cationic micelles, Journal of Membrane Science, 325 (2008) 69-80.

[116] M. Chen, C.T. Jafvert, Application of cross-linked stearic acid nanoparticles with dialysis membranes for methylene blue recovery, Separation and Purification Technology, 204 (2018) 21-29.

[117] M. Chen, K. Shafer-Peltier, S.J. Randtke, E. Peltier, Competitive association of cations with poly (sodium 4-styrenesulfonate)(PSS) and heavy metal removal from water by PSS-assisted ultrafiltration, Chemical Engineering Journal, 344 (2018) 155-164.

[118] C.W. Li, C.K. Liu, W.S. Yen, Micellar-enhanced ultrafiltration (MEUF) with mixed surfactants for removing $\mathrm{Cu}(I I)$ ions, Chemosphere, 63 (2006) 353-358.

[119] R.F. Rafique, Z. Min, G. Son, S.H. Lee, Removal of cadmium ion using micellar-enhanced ultrafiltration (MEUF) and activated carbon fiber (ACF) hybrid processes: adsorption isotherm study for micelle onto ACF, Desalination and Water Treatment, 57 (2015) 7780-7788. 
[120] L. Shen, N.P. Hankins, Removal of metallic ions at the parts per billion level from aqueous solutions using the polymer-surfactant aggregate process, Journal of Water Process Engineering, 30 (2019) 100486.

[121] C. Nura, A. Chattree, R. Singh, S. Nath, Removal of hexavalent chromium by mixed micelles of cetyl trimethyl ammonium bromide using micellar enhanced ultrafiltration, IJCS, 5 (2017) 627-631.

[122] C.A. Basar, C. Aydiner, S. Kara, B. Keskinler, Removal of $\mathrm{CrO} 4$ anions from waters using surfactant enhanced hybrid PAC/MF process, Separation and Purification Technology, 48 (2006) 270-280.

[123] R. Bade, S.H. Lee, S. Jo, H.-S. Lee, S.-e. Lee, Micellar enhanced ultrafiltration (MEUF) and activated carbon fibre (ACF) hybrid processes for chromate removal from wastewater, Desalination, 229 (2008) 264-278.

[124] L. Shen, J. Wu, S. Singh, N. Hankins, Removal of metallic anions from dilute aqueous solutions by polymer-surfactant aggregates, Desalination, 406 (2017) 109-118.

[125] L. Shen, N. Hankins, Metallic anion recovery from aqueous streams and removal agent recycle in the polymer-surfactant aggregate process, Desalination, 406 (2017) 67-73.

[126] J.-S. Yang, K. Baek, J.-W. Yang, Crossflow ultrafiltration of surfactant solutions, Desalination, 184 (2005) 385-394.

[127] M. Aoudia, N. Allal, A. Djennet, L. Toumi, Dynamic micellar enhanced ultrafiltration: use of anionic (SDS)nonionic (NPE) system to remove $\mathrm{Cr} 3+$ at low surfactant concentration, Journal of membrane science, 217 (2003) 181-192.

[128] M. Bielska, J. Szymanowski, Removal of methylene blue from waste water using micellar enhanced ultrafiltration, Water Research, 40 (2006) 1027-1033.

[129] C.A. Basar, A. Karagunduz, A. Cakici, B. Keskinler, Removal of surfactants by powdered activated carbon and microfiltration, Water Research, 38 (2004) 2117-2124.

[130] B. Channarong, S.H. Lee, R. Bade, O.V. Shipin, Simultaneous removal of nickel and zinc from aqueous solution by micellar-enhanced ultrafiltration and activated carbon fiber hybrid process, Desalination, 262 (2010) 221-227.

[131] X. Xu, H. Goh, K. Siow, L. Gan, Synthesis of polymerizable anionic surfactants and their emulsion copolymerization with styrene, Langmuir, 17 (2001) 6077-6085.

[132] M. Abe, K. Tsubone, T. Koike, K. Tsuchiya, T. Ohkubo, H. Sakai, Polymerizable cationic gemini surfactant, Langmuir, 22 (2006) 8293-8297.

[133] P.A. FitzGerald, K. Chatjaroenporn, X. Zhang, G.G. Warr, Micellization of monomeric and poly-omega-methacryloyloxyundecyltrimethylammonium surfactants, Langmuir, 27 (2011) 11852-11859.

[134] G. Chadha, Y. Zhao, Properties of surface-cross-linked micelles probed by fluorescence spectroscopy and their catalysis of phosphate ester hydrolysis, J Colloid Interface Sci, 390 (2013) 151-157.

[135] S. Zhang, Y. Zhao, Rapid release of entrapped contents from multi-functionalizable, surface cross-linked micelles upon different stimulation, Journal of the American Chemical Society, 132 (2010) 10642-10644.

[136] Y. Wu, W. Chen, F. Meng, Z. Wang, R. Cheng, C. Deng, H. Liu, Z. Zhong, Core-crosslinked pH-sensitive degradable micelles: A promising approach to resolve the extracellular stability versus intracellular drug release dilemma, Journal of controlled release : official journal of the Controlled Release Society, 164 (2012) 338-345. [137] M. Abe, T. Koike, H. Nishiyama, S.C. Sharma, K. Tsubone, K. Tsuchiya, K. Sakai, H. Sakai, Y.A. Shchipunov, J. Schmidt, Y. Talmon, Polymerized assemblies of cationic gemini surfactants in aqueous solution, J Colloid Interface Sci, 330 (2009) 250-253.

[138] D.L. Gin, J.E. Bara, R.D. Noble, B.J. Elliott, Polymerized Lyotropic Liquid Crystal Assemblies for Membrane Applications, Macromolecular Rapid Communications, 29 (2008) 367-389.

[139] J.-Y. Kim, C. Cohen, M.L. Shuler, L.W. Lion, Use of amphiphilic polymer particles for in situ extraction of sorbed phenanthrene from a contaminated aquifer material, Environmental science \& technology, 34 (2000) 
4133-4139.

[140] W. Tungittiplakorn, L.W. Lion, C. Cohen, J.-Y. Kim, Engineered polymeric nanoparticles for soil remediation, Environmental science \& technology, 38 (2004) 1605-1610.

[141] M. Veisi, S. Johnson, K. Shafer - Peltier, J.T. Liang, C. Berkland, M. Chen, R. Barati, Controlled release of poly (vinyl sulfonate) scale inhibitor to extend reservoir treatment lifetime, Journal of Applied Polymer Science, 136 (2019) 47225.

[142] M. Chen, K. Shafer-Peltier, M. Veisi, S. Randtke, E. Peltier, Complexation and precipitation of scale-forming cations in oilfield produced water with polyelectrolytes, Separation and Purification Technology, 222 (2019) 1-10.

[143] K. Shafer-Peltier, C. Kenner, E. Albertson, M. Chen, S. Randtke, E. Peltier, Removing scale-forming cations from produced waters, Environmental Science: Water Research \& Technology, 6 (2020) 132-143.

[144] L.-C. Shen, X.-T. Nguyen, N.P. Hankins, Removal of heavy metal ions from dilute aqueous solutions by polymer-surfactant aggregates: A novel effluent treatment process, Separation and Purification Technology, 152 (2015) 101-107.

[145] L. Shen, A. Lo, X. Nguyen, N. Hankins, Recovery of heavy metal ions and recycle of removal agent in the polymer-surfactant aggregate process, Separation and Purification Technology, 159 (2016) 169-176.

[146] Y.-H. Wu, L.-C. Shen, H.-Y. Hu, N.P. Hankins, W.E. Huang, An efficient microalgal biomass harvesting method with a high concentration ratio using the polymer-surfactant aggregates process, Algal research, 30 (2018) 86-93.

[147] M. Chen, N.P. Hankins, Interaction among branched polyethylenimine (PEI), sodium dodecyl sulfate (SDS) and metal cations during copper recovery from water using polymer-surfactant aggregates, Journal of Water Process Engineering, 34 (2020) 101170.

[148] L. Shen, N. Hankins, Metallic anion removal from dilute aqueous solutions using polymer-surfactant aggregate process: Effect of surfactant chain length, Journal of water process engineering, 20 (2017) 243-248. [149] P. Yenphan, A. Chanachai, R. Jiraratananon, Experimental study on micellar-enhanced ultrafiltration (MEUF) of aqueous solution and wastewater containing lead ion with mixed surfactants, Desalination, 253 (2010) 30-37.

[150] A. Deriszadeh, M.M. Husein, T.G. Harding, Produced water treatment by micellar-enhanced ultrafiltration, Environmental science \& technology, 44 (2010) 1767-1772.

[151] V. Innocenzi, M. Prisciandaro, F. Tortora, G.M. di Celso, F. Vegliò, Treatment of WEEE industrial wastewaters: Removal of yttrium and zinc by means of micellar enhanced ultra filtration, Waste Management, 74 (2018) 393-403. 